\title{
IETS OVER DE SCHEDELVEREERING BIJ DE VOLKEN VAN DEN INDISCHEN ARCHIPEL.
}

noon

\author{
De. G. A. WILREN.
}

De godsdienst van de volken, die den Indischen Archipel bewonen, bestaat onder meer nit de vereering van tal van onzichtbare, vrij rondwarende geesten, waaronder in de eerste plats de zielen der afgestorvenen. Bij die vereering stelt men zich deze zielen steeds op aarde, in zijne onmiddellijke nabijheid, voor. Voor zooverre zij toch in het zielenland gevestigd zijn, blijven zij hier niet onafgebroken, doch hebben zij het vermogen nu en dan onder de levenden terug te keeren, hetgeen zij niet alleen vrijwillig doen kunnen, doch ook wanneer zij daartoe opgeroepen worden. Waar het begrip nog bestaat dat de mensch meerdere zielen heeft, wordt zelfs eene daarvan veelal beschouwd als steeds op aarde te vertoeven, en deze is het dan die als beschermgeest door de nagelaten betrekkingen vereerd wordt. Een voorbeeld daarvan vinden wij bij de Niasers. Van de drie zielen, die zij aan den mensch toekennen, heeft de eerste, de noso of adem, geen voortbestaan, terwijl de tweede, die met de schaduw vereenzelvigd wordt, als bechu zi-mate naar het doodenrijk in de onderwereld gaat, en de derde, die in het hart gezeteld is, de noso-dodo, op aarde blijft voortleven in de gedaante van eene spin, moko-moko. Aan deze noso-dodo nu schrijft men eene bovennatuurlijke macht toe: zij is het die de lotgevallen der menschen in handen heeft en daarom als eene godheid beschouwd wordt ${ }^{1}$.

Als eene der meest oorspronkelijke uitingen van den dienst der afgestorvenen, is de gewoonte te beschouwen, om zich van beelden als mediums te bedienen. Deze gewoonte moet zich wel gevormd hebben in de laagste phase van ontwikkeling van het spiritisme en

\footnotetext{
${ }^{1}$ Zie onze verhandeling: Het animisme bij de volken van den Indischen Arshipel, blz. 5 en 164 ,
} 
onder den invloed van het toen reeds tot volle ontwikkeling gekomen fetisisme, toen men, met de voorstelling van vrij rondwarende geesten en zielen, van het bovenzinnelijke zich reeds een begrip had gevormd, doch dat begrip nog niet die hoogte bereikt had, dat men dat bovenzinnelijke van het zinnelijk waarneembare geheel kon scheiden. Zoo ontstond vanzelf de behoefte aan bepaalde voorwerpen, waarin of waarbij men zich de geesten der afgestorvenen, wanneer men zich met hen in betrekking wilde stellen, aanwezig denken kon. Niets natuurlijker nu dan dat men daarvoor beelden vervaardigde. In den Indischen Archipel bestaat dit gebruik heden ten dage nog bij verschillende stammen ${ }^{2}$. Zoo bij de evengenoemde Niasers. Van de afgestorvenen maakt men houten figuren, adju geheeten, waarin de ziel met het hart vereenzelvigd, de noso-dodo, die in de gedaante van eene moko-moko of spin blijft voortleven en als eene godheid wordt vereerd, overgebracht wordt. Aan de adju, die dus den geest van den overledene bevat, worden de offers gebracht, welke voor dezen bestemd zijn, en tot dit voorwerp wendt men zich, wanneer men dien geest wenscht te raadplegen ${ }^{3}$.

Behalve van beelden, bedient men zich bij de volken van den Indischen Archipel voor het verkeer met de zielen der afgestorvenen nog van andere voorwerpen. Bepaaldelijk wenschen wij hier de aandacht te vestigen op het gebruik van lichamelijke relieken. Dit is zelfs oorspronkelijker dan dat van beelden, en moet als een rechtstreeksch uitvloeisel beschouwd worden van de bij de natuurvolken algemeen bestaande voorstelling, dat de ziel ook na den dood eene zekere betrekking blijft onderhouden met, en dus gaarne vertoeft in de nabijheid van, het lichaam, dat haar voorheen tot verblijfplaats heeft verstrekt. Geen wonder dus dat men bij enkele volken er toe gekomen is, om te trachten, door inbalseming of op andere wijzen, de lijken zoolang mogelijk in ongeschonden staat te behouden, ten einde een voorwerp te hebben, waardoor men zich voortdurend met de zielen der afgestorvenen in betrekking kon stellen ${ }^{4}$. De moeielijk-

2 Zie dit uitvoeriger met voorbeelden angetoond in onze, in de voorgaande noot geciteerde, verhandeling, blz. 165 vv.

3 Animisme, blz. 170-171.

4 Zoo lezen wij, om hier een paar voorbeelden aan te halen, van de oude bewoners van Peru: "If the corpse was preserved, especially in the case of departed Incas, it was because the Peruvians believed that the soul which had left it still retained a marked predilection for its ancient abode and liked to return to it from time to timen (Réville, Lectures on the origin and growth of religion as illustrated by the native religions of Mexico and Peru, blz. 236). Bij de Caraiben werden ook 
heid aan het conserveeren van het geheele lijk verbonden, zal echter den wilde in de meeste gevallen er toe gebracht hebben, om alleen enkele relieken te bewaren en die bij de vereering te bezigen. "The soul", dit is toch, volgens de zoo juiste opmerking van Spencer, het geloof bij de natuurvolken, "present in the body of the dead man preserved entire, is also present in preserved parts of his body" ${ }^{\mathbf{5}}$. Vooral moet dit geloof bestaan ten aanzien van het lichaamsdeel, dat als de hoofdzetel der ziel beschouwd wordt, den schedel. Deze is het dan ook die bij den voorouderendienst in de eerste plaats als medium aangewend wordt.

Hetgeen duidelijk op den voorgrond moet worden gesteld, is dat het voorwerp, hetwelk als medium dienst doet, niet rechtstreeks vereerd wordt. Dat voorwerp is slechts een drager van de ziel, wordt slechts om de ziel, welke zich daarin bevindt, met eerbied behandeld. Duidelijk bemerken wij dit ten aanzien van de beelden, om bij het door ons aangehaalde voorbeeld te blijven, bij de Niasers. Zoodra er in de adju eene scheur komt, wordt zij als onbruikbaar weggeworpen. De ziel, of liever de moko-moko, waarin de ziel zich belichaamd heeft, wordt dan toch gezegd daaruit ontsnapt te zijn. Eene nieuwe adju moet er worden gemaakt, waarin de moko-moko, na teruggeroepen te zijn, weder gebracht wordt ${ }^{6}$. Bij enkele volken zien wij echter hoe, als eene latere wijziging van deze oorspronkelijke voorstelling, de beelden of relieken niet meer de middelen zijn, eenvoudig om zich in betrekking te stellen tot de geesten, doch hoe zij reeds om zichzelve, als met goddelijke macht begaafd, als fetisen dus, vereerd, en, als gelukaanbrengende en onheilwerende middelen, als amuletten en talismans, gebruikt worden. Vooral geldt dit van de schedels. Niet altijd is het echter even duidelijk te onderscheiden, in hoeverre deze nog blootelijk mediums zijn of reeds het karakter van fetisen aangenomen hebben. $\mathrm{W}_{\mathrm{ij}}$ stellen ons voor, in de volgende bladzijden, de schedelvereering - om deze benaming kortheidshalve te bezigen, ook waar er van eene rechtstreeksche ver-

de lijken wel eens door uitdroging tot mummies gemaakt en dan vereerd als verblijfplaatsen van de zielen der afgestorvenen (Müller, Geschichte der amerikanischen Urreligionen, blz. 209), terwijl wij bij Tylor (Primitive culture, dl. II, blz. 151) vermeld vinden, dat "the Marian-islanders should have kept the dried bodies of their dead ancestors in their huts as household gods, and even expected them to give oracles out of their skulls".

5 Spencer, Principles of sociology, dl. I, blz. 326 ,

o Animisme, bly, 171, 
eering nog geen sprake is - bij de volken van den Indischen Archipel na te gaan.

In de eerste plaats verdienen de Papuwa's van de Geelvinksbaai genoemd te worden. $\mathrm{Bij}$ de vereering van de afgestorvenen wordt bij hen hoofdzakelijk gebruik gemaakt van houten beelden, de bekende korwar's of korowâr's. Doch ook lichamelijke relieken worden daartoe aangewend. Soms, onder anderen gebeurt dit bij de bewoners van het eiland Jobi of Jappen en verder bij de stammen, die in de binnenlanden van de Dorei-baai gevestigd zijn, wordt het geheele lijk gemummificeerd, door het boven een vuur langzaam uit te drogen, vervolgens in huis gebracht en daar tegen den muur gezet of aan den zolder opgehangen ${ }^{\boldsymbol{7}}$. Hoewel wij dit niet uitdrukkelijk vermeld vinden, is het toch zeer waarschijnlijk, dat die dus tot mummies vervormde lijken, zoo thans niet meer, dan toch oorspronkelijk bij de zielenvereering als mediums hebben gediend. Nu wordt daartoe meer van enkele relieken, bepaaldelijk van den schedel, gebruik gemaakt. Niet bij alle afgestorvenen wordt dit echter gedaan, doch alleen bij eerstgeborenen. Is zoo iemand overleden, dan wordt slechts de romp begraven, terwijl het hoofd bewaard wordt. Wanneer na verloop van twee of drie maanden van dit laatste de vleeschdeelen geheel vergaan zijn, komen de vrienden en bekenden in het sterf huis samen. Onder het zingen van treurliederen, worden nu van eene bijzondere soort hout een neus en een paar ooren gesneden en deze aan het doodshoofd bevestigd, terwijl in de oogholten, ter vervanging van de oogen, kleine, ronde vruchtpitten gestoken worden. Na afloop van dit alles, wordt er een maaltijd aangelegd ter eere van den overledene, nu door dat doodshoofd vertegenwoordigd, zooals het, de kruin door een doek omwonden en het aangezicht met roet en kalk beschilderd, op een blok tusschen de gasten aan den disch is geplaatst: hij ontvangt aldus zijn behoorlijk aandeel van de aangerechte spijzen. Op die wijze wordt de schedel van den afgestorvene verheven tot een huisgod, en daarna zorgvuldig bewaard. Bij de zielenvereering nu wordt daarvan hetzelfde gebruik gemaakt als van de beelden, de korwar's. Gelijk het beeld, is de schedel het middel,

7 Animisme, blz. 176-177. - Ook bij de stammen van de Zuidwestkust, bepaaldelijk de Papuwa's van Mairasi, het gebergte ten Noorden van de Triton-baai, worden de lijken, ongeveer eene maand, boven een vuur uitgedroogd, daarna echter niet in huis bewaard, doch naar het boseh gebracht en daar in eene spelonk of rotshol nedergelegd en onder boombladeren verborgen (Animisme, blz. 177). 
waardoor men zich met den overledene in betrekking stelt, wanneer men hem over het een of ander wenscht te raadplegen ${ }^{\mathbf{8}}$. Hier en daar, bepaaldelijk op de eilanden Roon en Beak of Biak, komt het gebruik van beiden zelfs gecombineerd voor, in dien zin dat men van den afgestorvene, doch weder alleen wanneer deze een eerstgeborene is, een beeld vervaardigt en in het hoofd, dat daartoe van boven open en hol uitgesneden is, den schedel plaatst ${ }^{\mathbf{9}}$.

Sterk geprononceerd komt de vereering van de afgestorvenen voor op de Moluksche eilanden, waarheen wij ons nu verplaatsen, en ook hier wordt daarbij dikwijls, behalve van beelden, van schedels gebruik gemaakt. Het meest merkwaardige voorbeeld daarvan vindt men op de Timorlaoet-eilanden. Wanneer iemand gestorven is, wordt het lijk of, in eene kist, op eene houten of bamboezen stellage aan het strand geplaatst, ò, in matten gewikkeld, tusschen de takken van hooge boomen gelegd. Zijn de vleeschdeelen geheel verteerd, dan worden de beenderen verzameld en begraven, de schedel echter, na in zeewater gewasschen en met olie bestreken te zijn, op eenen schotel in huis bewaard. Bovendien wordt er een beeld van den overledene vervaardigd. Zoowel dat beeld nu als de schedel wordt bij de vereering van den afgestorvene gebezigd. Wenscht men namelijk de ziel te raadplegen, dan wordt zij, onder het brengen van offers en het wuiven met een geel zijden doek, opgeroepen ${ }^{10}$. Die ofiers nu worden geplaatst zoowel bij den schedel als bij het beeld, en men laat het geheel aan de keuze van de ziel over, in welk van deze

s Evenals bij de Niasers, schijnt het bij de Papuwa's de voorstelling te zijn, dat het beeld, resp. de schedel, aan de ziel, die vereerd wordt, duurzaam tot verblijfplaats strekt. Deze ziel is dan ook bij hen eene andere dan die, welke naar het zielenland gaat. Van de Papuwa's van het eiland Roon althans wordt ons dit uitdrukkelijk medegedeeld. Deze nemen het bestaan aan van twee zielen, waarvan de eene, die bij het overlijden deze aarde verlaat en naar het schimmenrijk vertrekt, in het bloed haren zetel heeft, terwijl de andere, die hier blijft en in het medium, het beeld, resp. den schedel, wordt gebracht, met de schaduw vereenzelvigd wordt.

9 Zie voor het, in den tekst en in de voorgaande noot, medegedeelde, onze verhandelingen: Het animisme bij de volken van den Indischen Archipel, blz. 165-167 en 177-178, en Iets over de Papuwa's van de Geelvinksbaai, Bijdragen tot de T. L. en Vk. van Nederl. Indië, כe volgreeks, di. II, blz. 609-612 en 613-614, en de daar aangehaalde bronnen.

10 Anders dan bij de Niasers on Papuwa's, is het bij de bewoners van de Timorlaoet-eilanden de voorstelling, dat de ziel niet duurzaam in het beeld, resp. den schedel, gevestigd is, doch dat zij slechts daarin tijdelijk haren zetel neemt, wanneer zij daartoe wordt opgeroepen. De ziel toch, die hier vereerd wordt, is dezelfde als die, welke na den dood naar het zielenland gaat. 
beide voorwerpen zij haren intrek wil nemen. Aan de omstandigheid dat er eene vlieg zich op het eene dan wel op het andere offer nederzet, of de strooken palmbladeren, die aan de offerplaatsen bevestigd zijn, zich bewegen, herkent men waar de ziel zich bevindt. Het dus aangewezen voorwerp wordt dan als medium aangewend 11. Behalve op de Timorlaoet-eilanden, vindt men de schedelvereering, in de Molukken, nog op Boeroe en op Ceram. Bij de stammen, die de Noordkust van het eerstgenoemde eiland bewonen, en bij die, welke in het gebergte rondom het meer Wakolo gevestigd zijn, bestaat namelijk de gewoonte, om de schedels van de afgestorven famieliebetrekkingen te bewaren en te aanbidden ${ }^{12}$. Ook Forbes ${ }^{13}$ maakt van deze gewoonte gewag. "When the body is decomposed", aldus schrijft hij, "the son or nearest relative disinters the head, wraps a new cloth about it, and places it in the huma-koin ${ }^{14}$ at the back of his house, or in a little hut erected for it near the grave. It is the representative of his forefathers whose behests he holds in the greatest respect". Wat Ceram betreft, vermeldt de Heer Riedel dat bij de Patalima's, eenigen tijd na de begrafenis, de schedel van den doode uit het graf gehaald, gereinigd en in een daarvoor gebouwd hutje, tegelijk met een weinig sirih-pinang en tabak, geplaatst wordt ${ }^{15}$. Dat de dus bewaarde doodshoofden werkelijk meer of min vereerd worden, blijkt uit de mededecling van den te Amahei, op de Zuidkust van het eiland, gevestigden Zendelingleeraar De Vries. "Bij de groote offerfeesten", schrijft deze, "treden zij (de dati- of familiehoofden) op als priesters en brengen zij als zoodanig hulde aan een twintigtal schedels. Uit een daarvan wordt de door den offerpriester gewijde sagoeweer (palmwijn) gedronken "1 16 .

Niet alleen in het Oosten van den Archipel, doch ook in het

${ }^{11}$ Animisme, blz. 168 en 178-179. Vergelijk ook: Riedel, De sluik- en kroesharige rassen tusschen Selebes en Papua, blz. 281, 305-306 en 307 ; Kolff, Reize door den weinig bekenden Zuidelijken Moluksehen Arohipel, blz. 238 en 240 .

12 Zie onze: Bijdragen tot de kennis der Alfoeren van het eiland Boeroe, Verhandelingen van het Bataviaaseh Genootschap van Kunsten en Wetensohappen, dl. XXXVIII, blz. 23.

1s A naturalist's wanderings in the Eastern Archipelago, blz. 405.

14 Forbes schrijft matakau. Dit is echter (zie mijne aankondiging van zijn werk, Indisehe Gids, jaarg. 1886, dl. II, blz. 1589) onjuist. De huma-koin, in het $\mathrm{Ma}-$ leisch rumah-p̌mmali, is het huisje, veelal niet meer dan een afdsk, bestemd voor de vereering der afgestorvenen.

15 Riedel, De sluik- en kroesharige rassen tussehen Selebes en Papua, blz. 143-144.

10 Kerkelijk rapport van den Zendelingleerasr De Vries, Tijdschr. v. Ind. T. L. en Vk., dl. XXII, blz. 251. 
Westen komt de schedelcultus voor. In de eerste plaats hebben wij de aandacht te vestigen op de Dajaks. Over het algemeen treedt bij hen de aanbidding van de zielen der afgestorvenen, als goddelijke machten, minder sterk op den voorgrond, dan dit bij de andere volken van den Indischen Archipel het geval is. Toch ontbreekt het bij hen niet aan duidelijke sporen van eene reliekenvereering. Van de Zee-Dajaks van Sarawak lezen wij onder anderen : "Great warriors have been sometimes buried for a time and then exhumed, and their relics sacredly kept by their descendants in or near their houses, or it may be, on the spur of a neighbouring hill, with the object of securing the departed ancestor as a tutelary spirit" ${ }^{\mathbf{1 7}}$. Ook de relieken van andere dooden schijnen dikwijls bewaard te worden. Bij elke feestelijke gelegenheid worden offers daaraan gebracht, "in return for which these honoured dead are expected to confer substantial favours upon their living descendants" 18. - Eene bepaalde schedelvereering treft men in het Zuidoosten van het eiland aan, bij enkele stammen der Olo-Maanjan 19 . Zoo bij die, welke langs den bovenloop der Karau gevestigd zijn. In het verslag van eene door hem in 1857 in dit gebisd gelane reis, vermeldt de heer Bangert, sprekende van zijn verblijt in de kampong Modok: "Als eme bijzonderheid toonde Ngabehi Anom (het hoofl der kampong) mij zijns vaders sebedel. Dit voorwerp; als on heiligdom bewaral, wias in een fraai vervandigd kistje geborgen, waarin het op een gewoon tafelbord stond. 13ij het opeanes van het kistje werlen er renkwerken gebrand en eenige onverstaanbare woorlen gepreveld. Wene der nrownen lawam toen nalerbij en sloeg cen hoenderei stak, noodat de inhoud langs het dooulshootl vloeide, hetgera een afsedurelik gencht opleverde. De onde Ngabehi Anom zalfle daarop het vocrierp med lokosolie en sloot ver-

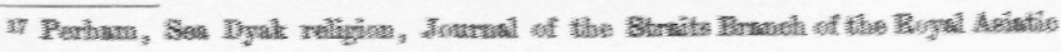

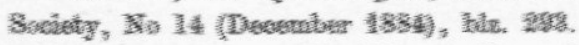

16 Pertum, 6. 6., ble.

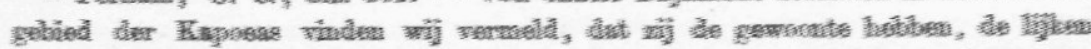

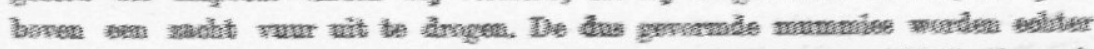

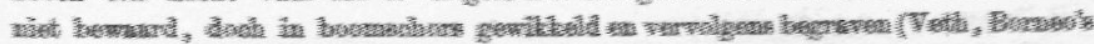

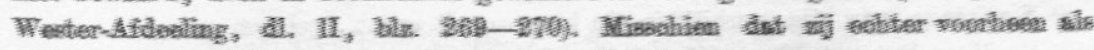

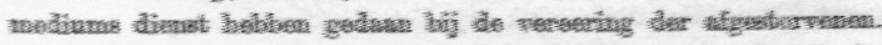

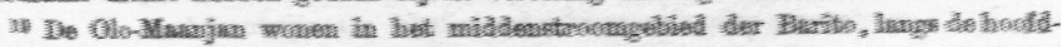

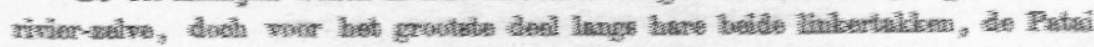

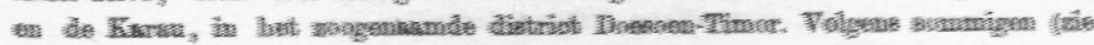

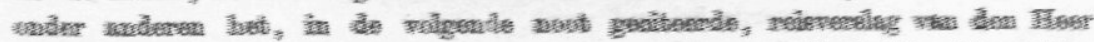

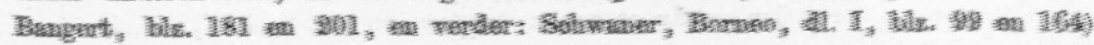

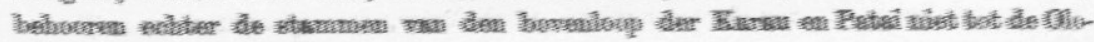

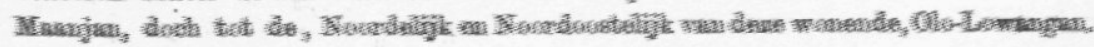


volgens het kistje, dat uiterst zorgvuldig tusschen de hanebalken van het huis werd geborgen. Hij vertelde mij voorts, dat dit bewaren van de schedels der afgestorvenen algemeen in zwang was bij de voorname personen, en dat men aan die relieken groote waarde hechtte" 20 . Ook bij de stammen van Sihong, het landschap bespoeld door de rivier van dien naam 21, vond de Heer Bangert hetzelfde gebruik. Wanneer een hoofd sterft, aldus lezen wij, wordt met zijn lijk als met dat van ieder ander gehandeld (dat wil zeggen: verbrand), uitgenomen den schedel, die bijtijds verwijderd en als een heiligdom bewaard wordt ${ }^{22}$. Doch niet alleen bij de Olo-Maanjan, die zijwaarts van de Barito, langs de takken van deze rivier, doch ook bij die, welke langs den hoofdstroom-zelven gevestigd zijn, schijnt de schedelcultus voor te komen, gelijk uit eene aanteekening in het genoemde verslag van den Heer Bangert blijken kan ${ }^{23}$. Wij zien dus hoe bij de Olo-Maanjan de schedels der afgestorvenen niet alleen bewaard worden, doch dat zij ook voorwerpen zijn eener godsdienstige vereering. Wat men zich van die schedels voorstelt, blijkt niet uit de mededeelingen van den Heer Bangert. Niet onwaarschijnlijk is het echter, dat zij als beschermende fetisen, met andere woorden als amuletten, als talismans, dienst doen. De Heer Grabowsky deelt althans mede, dat in het landschap Sihong de schedel van den overgrootvader van den bekenden Suta Ono 24 als een pangantoho vereerd wordt, en daaraan op zekere tijden offers worden gebracht ${ }^{25}$. Een pangantoho nu is, gelijk wij straks zullen zien, een talisman, die van zijnen bezitter ziekten en andere onheilen afweert. - Nog bij een tweetal stammen in het Zuidoosten van

20 Bangert, Verslag der reis in de binnenwaarts gelegen streken van DoesoenIlir, Tijdschr. v. Ind. T. L. en Vk., dl. IX, blz. 196-197.

${ }_{21}$ De Sihong is eene rivier, die het district Doesoen-Timor, eerst in Westelijke, dan, onder de benamingen Napo en Krambas, in Zuidelijke richting, doorstroomt en zich vervolgens met de, uit het Noordoosten komende, Patai (zie noot 19 hierbuven) vereenigt, niet ver boven de plats, waar deze zich in de Barito stort. Beneden dit vereenigingspunt heet de Patai eigenlijk Sirau.

22 Bangert, O. c., blz. 155.

23 Sprekende van zijn verblijf in de kampong Boentok, gelegen aan de Barito, zegt de Heer Bangert (O. c., blz. 208): "Ook hij (het hoofd der kampong) toonde mij den in groote eere gehouden wordenden schedel van zijnen vader".

24 Suta Ono was districtshoofd van Doesoen-Timor, en bewees als zoodanig den Hollanders, tijdens den opstand van 1859 , belangrijke diensten, waarvoor hij zelfs met de Militaire Willemsorde beloond werd.

25 "Man sagt", voegt Grabowsky or echter aan toe, "er (der Schädel) sei beim Verbrennen der Leiche zu Kupfer geworden" (Grabowsky, Der Distrikt Dusson-Timor in Südost-Borneo und seine Bewohner, Ausland, jaarg. 1884, blz. 470). 
Borneo, de Olo-Lowangan en de Tundjung-Dajaks 26 , bestaat het gebruik om de schedels der afgestorvenen op eene bijzondere wijze te bewaren. Laatstgenoemden doen ze, volgens Von de Wall, in potten, die zij op eene soort van stelling boven den haard plaatsen $\mathbf{2 7}$. Wat de Olo-Lowangan betreft, deelt de Heer Grabowsky mede, dat het lijk, na voorloopig begraven te zijn, bij het vieren van het doodenfeest, weder opgedolven wordt. De beenderen worden dan schoongemaakt. In het bijzonder geschiedt dit met den schedel, die dan in een pyramidevormig, met roode en witte arabesken beschilderd, toestel gelegd en in de woning opgehangen wordt, terwijl de balian's, mannelijke en vrouwelijke shamanen, er dansen omheen uitvoeren. Intusschen wordt er vóór het huis, of in de nabijheid daarvan, een fraai bewerkte ijzerhouten pal opgericht, van ongeveer 1.25 Meter lengte, waarop een termpajan of balanga ${ }^{28}$ geplaatst wordt, die met gestreept katoen versierd en gedeelte!ijk met grint gevuld is. Op deze grint wordt dan de schedel, met de overige beenderen, gelegd, waarna de pot met een houten deksel gesloten wordt 29 . Van eene vereering van de dus bewaarde schedels schijnt, noch bij de Tundjung-Dajaks, noch bij de Olo-Lowangan, sprake te zijn, althans vinden wij niets daaromtrent vermeld. Echter is het niet onwaarschnijlijk, dat zij primitief wel als beschermende fetisen, als amuletten, dienst hebben gedaan, en als zoodanig voorwerpen van aanbidding zijn geweest, gelijk dit nu nog het geval is bij de Olo-Maanjan.

Van de volken in het Westen van den Archipel verdienen de Bataks nog genoemd te worden. De schedelcultus wordt bij hen aangetroffen onder de stammen, die om en bij het meer van Toba gevestigd zijn. "Der Häuptling von Pordopur, einer kleinen Insel im Tobameere, bewahrt den Schädel seines Vaters, und bei Opferfesten, die dem Vater gelten, tanzt er mit ihm und ruft ihn um Ehre und Reichthum an". Aldus de Heer Ködding in zijne verhandeling "Die Batakker auf Sumatra" ${ }^{3} \dot{0}$. Het gebruik schijnt intusschen

26 De Olo-Lowangan wonen, gelijk reeds hierboven in noot 19 werl opgemerkt, ten Noorden en ten Noordoosten van de Olo-Maanjan, terwijl de Tundjung-Dajaks in het rijk van Koetei, langs den rechteroever der Mahakam, gevestigd zijn.

${ }^{27}$ Von de Wall, Beknopt overzigt van het rijk van Koetei, Indisch Arehief, jaarg. 1849, dl. I, blz. 156.

28 De tempajan's of balanga's zijn de bekende heilige potten van de Dajaks. Zie verder hierover Aanteekening I aan het slot vau dit opstel.

29 Grabowsky, Die Olo-Lowangan in Südostborneo, Ausland, jaarg. 1888, blz. 583.

so Globus, dl. LIII, blz. 92.

5e Volgr IV. 
algemeener te zijn, dan uit dit bericht is op te maken. In Toba, heet het namelijk in een opstel, voorkomende in de "Sumatra-Courant" van den 4 April $1878^{31}$, bestaat nog de gewoonte om de schedels van de afgestorvenen te bewaren. Het lijk blijft in eene kist, waarvan de naden goed met hars dichtgemaakt zijn, verscheidene jaren in eene sopo of loods staan, totdat men eindelijk zonder zwarigheid den schedel kan verwijderen. Deze wordt dan, na gereinigd en met een zijden hoofddoek en gouden ringen versierd te zijn, door den oudsten zoon naar de markt gebracht en aan de daar aanwezigen vertoond. Hierop volgt eene reeks van feesten ter eere van den overledene, waartoe de geheele familie twintig tot dertig buffels bijeenbrengt, welke allen geslacht worden. Bij alle huiselijke aangelegenheden, en verder in den oorlog, speelt de schedel, als vertegenwoordiger van den geest van den afgestorvene, eene voorname rol. Wordt het voorwerp ontvreemd, dan geldt dit als een voorteeken van ongeluk, en is het tevens de grootste schande, die eene familie kan treffen.

Tot dusverre beschouwden wij alleen de schedelvereering als uiting van den dienst der voorouders. Doch de geesten, hoewel zij in de eerste plaats schutsgoden zijn voor de achtergebleven familiebetrekkingen en vrienden, kunnen dit ook voor vreemden, ja zelfs voor vijanden wezen. Slaagt men er toch in, den schedel van iemand in handen te krijgen, dan heeft men ook diens ziel in zijne macht en kan deze aan zich dienstbaar maken, na haar door offers te hebben verzoend. Deze beschouwing heeft tot het koppensnellen geleid. In het wezen der zaak berust dit koppensnellen, het gebruik om iemand te dooden en zijnen schedel te bewaren, opdat de daarmede vereenzelvigde ziel een schutsgeest zij voor den bezitter, op dezelfde voorstelling als de zooeven besproken gewoonte bij den voorouderendienst, om de eene of andere reliek, in de eerste plaats ook den schedel, van eenen overledene te behouden en als middel te gebruiken, ten einde zich met hem in betrekking te stellen. Natuurlijk dat deze bedoeling van het koppensnellen niet overal even duidelijk meer bemerkbaar is, ja zelfs hier en daar verloren is gegaan, zoodat het verzamelen van schedels nu met geen ander doel geschiedt, dan om een bewijs van moed te geven, daar hij, die het grootste aantal hoofden weet te vertoonen, als de grootste held wordt beschouwd.

31 Zijn wij wel onderricht, dan is dit opstel vervaardigd naar de mededeelingen van een der in Toba gevestigde Duitsche Zendelingen. 
Het doel van het koppensnellen is dus in de met den schedel vereenzelvigde ziel van den verslagene een schutsgeest te vinden ${ }^{3} \mathbf{1}_{\mathrm{a}}$. De buitgemakte schedel is dus voor zijnen bezicter een talisman, eene amulet. Men herinnert zich hoe volgens Herodotus de Tauriërs, de oude bewoners van de Krim, de vijanden, die in hunne handen vielen, de hoofden afsneden en deze op lange palen geplaatst, boven het rookgat op de daken stelden, in de meening dat zij alsdan de woning bewaakten ${ }^{32}$. Even duidelijk komt deze bedoeling van het koppensnellen uit bij de Dajaks van Borneo. Pangantoho heet bij de Olo-Ngadju, in het Zuidoosten van dit eiland, een talisman, die van zijnen bezitter allerlei onheilen en ziekten afweert, en die daarom met bijgeloovigen eerbied behandeld, ja zelfs godsdienstig vereerd wordt, onder anderen door het brengen van offers. Behalve uit allerlei voorwerpen, beenderen van dieren, vischgraten, stukjes hout, steentjes, enz., bestaan de pangantoho's riet zelden uit menschenschedels ${ }^{33}$. In enkele gevallen kunnen deze van afgestorven bloe "erwanten zijn, gelijk wij dit zooeven reeds opgemerkt hebben. Doch veelal schijnen zij, blijkens de kenteekenen die zij, zooals de Heer Grabowsky ons mededeelde, vertoonen, van met een scherp werktuig van den romp te zijn afgescheiden, van in den krijg of bij sluipmoord gedoode vijanden te wezen 33 a. Overigens zien wij nog uit een eigenaardig gebruik, dat bij sommige plechtigheden van de gesnelde schedels gemaakt wordt, hoezeer deze het karakter van eenen

s1a Men heeft twee wijzen van koppensnellen, die waarbij men opzettelijk iemand, meestal door sluipmoord, doodt, en die waarbij men de hoofden van de in den oorlog gevallenen afsnijdt en medeneemt. De meeste volken hebben beide wijzen, enkele alleen de laatstgenoemde. Bij het verheffen van eenen schedel tot fetis, is het onversohillig, op welke van de twee wijzen men dien verkregen heeft, of het dus een schedel is van iemand, opzettelijk daarvoor door sluipmoord gedood, of van een in den oorlog gevallene.

32 Herodotus IV, 103. - Zie overigens, over het gebruik van schedels als amuletten voorheen in Europa, onder meer, de interessante mededeeling van Dr. W. Pleyte "Schedelvereering in Friesland".

ss Hardeland, Dajaksch woordenboek, i. v. pangantoho; Grabowsky, Ueber verschiedene weniger bekannte Opfergebräuche bei den Olo-Ngadju in Borneo, Internationales Archiv für Ethnographie, dl. I, blz. 133.

ssa Zoo werd dit duidelijk door Prof. Virchow geconstateerd bij een drietal schedels, door den Heer Grabowsky medegebracht, welke, volgens eene door dezen aan mij gedane mededeeling, als pangantoho dienst hebben gedaan. "Um das Forazen magnum", aldus schrijft Virchow van een dier schedels, "sieht man die grosse, beim Abhauen des Kopfes entstandene Oeffnung, welche die ganze Umgebung des Hinterhauptsloches, die Apophysis basilaris, den linken Warzenfortsatz und einen grossen Theil der Hinterhauptsschuppe weggenommen hat. Sie ist 
talisman, eene amulet hebben. Zoo verhaalt de Heer Grabowsky onder anderen, dat toen hij, op eene reis in de bovenlanden van ZuidoostBorneo, in de Dajaksche kampong Roedjak kwam, bij het feest te zijner verwelkoming, zulk een schedel, met bladeren van den pinang- of arecapalm versierd, voor den dag gebracht en aan een hampatong of beeld gebonden werd, waarom de mannen eenen dans uitvoerden. Aan het einde daarvan, werd de schedel, nadat allen daartoe nedergehurkt waren, zegenend over de hoofden van de aanwezigen gezwaaid, bij welke ceremonie oude vrouwen zelfs vooraaudrongen, om er deel aan te nemen ${ }^{34}$. Blijkt dus bij de Olo-Ngadju duidelijk het gebruik van de gesnelde schedels als talismans, als amuletten, niet minder is dit het geval bij de Land- en Zee-Dajaks van Sarawak. Van de laatstgenoemden lezen wij in het werk van Low, dat bij den terugkeer van eenen sneltocht ter zee, niet alleen ter eere van de overwinnaars, doch ook van de buitgemaakte hoofden, groote feesten worden gegeven. De schedel wordt, omwikkeld in bladeren van den nipah-palm, die op eene bijzondere wijze gevlochten en gevouwen zijn, aan wal gebracht, maanden lang met de grootste onderscheiding behandeld, met allerlei liefkozende woordjes toegesproken, en van de lekkerste beten van elken maaltijd en van sirihpruimen en sigaretten voorzien, die hem tusschen de ontvleesde lippen gestoken worden. Niets van dit alles geschiedt uit spotternij. Het doel is bepaaldelijk, den geest des verslagenen te verzoenen en zich van zijne goede gezindheid te verzekeren. Hem wordt dan ook ingeprent, zijne vroegere vrienden te haten, en de leden van den stam, waarin hij nu is opgenomen, met toewijding te dienen en steeds met hen te zijn ${ }^{35}$. Hetzelfde heeft, volgens Spenser St. John, ook bij de Land-Dajaks na eenen sneltocht plaats. Eeu offer, uit allerlei spijzen bestaande, wordt dan aan de schedels, of liever aan de daarmede vereenzelvigde zielen van de gedooden, gebracht, opdat deze, daardoor verteederd en bevredigd, geen wrok koesteren noch den overwinnaars rampen of onheilen be-

nach links hin grösser und hat hier schärfere Ränder, während die Apophysis abgebrochen wurde. Man kann wenigstens ein Dutzend scharfer, schräg von rechts nach links gerichteter Hiebe zählen. Auch an den Nasenbeinen sieht man zwei scharfe, von oben her geführte Hiebe, einen an der Wurzel, einen etwas tiefer, der den grössten Theil der Nasenbeine abgesprengt hat" (Verhandlungen der Berliner anthropologischen Gesellschaft, 1885, blz. 270-271).

s4 Grabowsky, Dajakische Sitten und religiöse Gebräuche, Globus, dl. XLII, blz. 214. - Volgens eene mij door den Heer Grabowsky gedane mededeeling, heeft eene dergelijke plechtigheid meer plaats en zijn het bepaaldelijk gesnelde schedels, welke daarbij gebruikt worden.

so Low, Sarawak, blz. 206-207. 
rokkenen mogen ${ }^{36}$. Hoezeer het bezit van een hoofd als gelukaanbrengend, als heilrijk in zijne gevolgen wordt beschouwd, vinden wij hier uitdrukkelijk vermeld. Van de offerfeesten der Iand-Dajaks sprekende, zegt namelijk laatstgenoemde schrijver, dat het doel daarvan is, om te maken dat de rijst goed gedije en dat er overvloed vam wild in de bosschen en van visch in de rivieren zij, om eene goede gezondheid deelachtig te worden en aan de vronwen den zegen der vruchtbaarheid te verzekeren. Dit alles nu meent men het gemakkelijkst en het zekerst te kunnen bereiken door het buitmaken en daarna het feestelijk onthalen van eenen schedel ${ }^{37}$. De reden van deze beschouwing ligt voor de hand. In elk versch gesneld hoofd heeft men eenen schutsgeest meer bij de schutsgeesten, welke men reeds bezit, een schutsgeest bovendien die, onder den invloed van de pas ontvangen eerbewijzingen bij de plechtigheid te zijner inwijding, vanzelf gunstig gestemd moet zijn en den eigenaar dns gelnk aanbrengen moet.

Gelijk uit het laatst aangevoerde kan zijn gebleken, is het bij de Zee- en Land-Dajaks van Sarawak vooral uit de plechtigheden, die na eenen sneltocht plaats hebben, dat men duidelijk zien kan, hoezeer de buitgemaakte schedels als beschermende fetisen beschouwd en vereerd worden. Ook bij de andere volken van den Indischen Archipel vinden wij dergelijke plechtigheden vermeld. Men stelt zich met deze plechtigheden voor, de geesten der verslagenen te verzoenen, hen tot vrienden en bondgenooten te maken. Zoo lezen wij onder anderen van de Timoreezen, dat na afloop van eenen krijgstocht, de gesnelde schedels op pieken gestoken worden, waaromheen dan gedanst wordt, terwijl liederen worden aangeheven, waarin men het lot der gedooden beklaagt en hun vergiffenis verzoekt voor het vergoten bloed. "Weest niet vertoornd!" aldus heet het, "dat uw hoofd bij ons is; waren wij minder gelukkig geweest, dan zou misschien ons hoofd in uwe kampong zijn tentoongesteld. Wij hebben de offerande volbracht om $u$ te bevredigen. Uw geest moge nu rusten en ons vrij laten van kwellingen". Daarbij worden aan elken schedel offerspijzen, rijst en varkensvleesch, voorgezet, terwijl de meo, de voorvechter, hem met de volgende woorden tot eten uitnoodigt: "O Toflebo, behaagt $\mathrm{u}$ deze plaats tot rustpunt, ontbied dan uwe betrekkingen, om het even hoevele, bij $u$; roep hen herwaarts, of wilt gij alleen eten?

${ }^{36}$ Spenser St. John, Life in the forests of the far East, dl. I, blz. 187.

s7 Spenser St. John, O. c., dl. I, blz. 193-194. 
Eet dan; verzadig u met varkensvleesch en rijst" ${ }^{3 \mathbf{8}}$. - Dezelfde strekking hebben ook de koppensnellersfeesten bij de Alfoeren van Ceram. Ook bij hen worden, onder het dansen rondom de pas buitgemaakte schedels, liederen aangeheven, die " eene bede om verzoening bevatten, opdat de geest van den verslagene geen rouw of ongeluk brenge over de overwinnaars " $\mathbf{3 9}$.

Het begrip, dat men, door zich in het bezit te stellen van iemands schedel, ook diens ziel in zijne macht krijgt, deze aan zich dienstbaar maken en tot schutsgeest aanwenden kan, komt niet minder duidelijk uit bij de Bataks. Voorheen moet ook het koppensnellen bij dit volk bestaan hebben. Dit blijkt onder anderen uit eene mededeeling van den Venetiaan Nicolò Conti, die in het begin van de vijftiende eeuw Indië bezocht. De "Batech" op het eiland "Sciamuthera", schrijft hijj, zijn menscheneters, die in voortdurenden strijd leven met hunne naburen. Wanneer zij iemand gevangen genomen hebben, slaan zij hem het hoofd af, eten het vleesch op en bewaren den schedel, dien zij op hoogen prijs stellen en als betaalmiddel bezigen, zoodat hij, die de meeste schedels bezit, als de rijkste beschouwd wordt ${ }^{40}$. Bij latere schrijvers vinden wij dit bericht bevestigd. Zoo lezen wij in het verslag van de, in 1824, door de Heeren Burton en Ward in het land der Bataks ondernomen reis, dat in de woningen de ruimte tusschen de zoldering en het dak, niet alleen als rijstschuur gebruikt wordt, doch ook als bergplaats van de hoofden der in den krijg gevallen vijanden ${ }^{41}$. Evenzoo deelt nog Marsden in zijn, in 1811 verschenen, "History of Sumatra" mede, dat de Bataks de gewoonte hebben, de koppen van hen, die in den krijg gevangen genomen, geslacht en opgegeten zijn, te bewaren en als zegeteekenen in de sopo's of gemeentehuizen op te hangen ${ }^{42}$. Niet minder merkwaardig is zeker hetgeen wij bij

38 Sal. Müller, Reizen en onderzoekingen in den Indischen Arohipel, dl. II, blz. 252-253; Gramberg, Eene maand in de binnenlanden van Timor, Verhandel. v. h. Bat. Gen. v. K. en W., dl. XXXVI, blz. 216-217; Reinwardt, Reis naar het Oostelijk gedeelte van den Indischen Archipel, blz. 342-343. Zie ook: Heymering, Een inlandsche oorlog op het eiland Timor, Tijdschr. v. Nederl. Indië, jaarg. 1846, dl. III , blz. 219-220, en Donselaar, De christelijke zending in de residentie Timor, Mededeelingen v. w. h. Nederl. Zend. Gen., dl. XXVI, blz. 275.

39 Ludeking, Schets van de residentie Amboina, blz. 60-61.

40 Zie de vertaling van de reizen van Nicolò Conti bij: Major, India in the fifteenth century, being a collection of narratives of voyages to India, blz. 9 .

41 Burton en Ward, Verslag van eene reis in het land der Bataks, Bijdragen tot de T. L. en Vk. v. Nederl. Indië, nieuwe volgreeks, dl. I, blz. 277.

42 Marsden, History of Sumatra, blz, 392. Zie ook: Neumann, Het Pane- en 
den Arabischen schrijger Ibn al-Wardî ${ }^{43}$ verhaald vinden, dat namelijk in het "land van de kamfer" menscheneters aangetroffen worden, diẹ de schedels van hen, die zij verslonden hebben, met kamfer en andere aromatische stoflen vullen, en vervolgens in humne woningen ophangen en vereeren. Indien zij iets willen ondernemen, werpen zij zich voor deze schedels op hunne knieën neder, om ze te raadplegen. Indien de gissing van Prof. Van der Lith, die in de belangrijke aanteekeningen, door hem aan zijne uitgave van den "Kitâb "adjâib al-Hind" toegevoegd, op dit bericht de aandacht gevestigd heeft, juist is, dat hier de Bataks bedoeld zijn ${ }^{44}$, dan zien wij hoe ook bij dit volk voorheen het koppensnellen, het verzamelen van schedels, niet alleen geschiedde om krijgsroem te verwerven, doch ook met religieuse bedoelingen, om in de met die schedels vereenzelvigde zielen van de verslagenen schutsgeesten te erlangen. Nog heden ten dage vinden wij dan ook een overblịjssel hiervan in het geloof aan den zoogenaamden pangulubalang ${ }^{45}$. De pangulubalang is eene ámulet, een talisman, die door den datu, den wichelaar, bereid wordt uit verschillende vreemdsoortige ingrediënten, als : ineengerolde jonge bladeren, de van rijpheid geel geworden bladstelen van sommige gewassen, aarde, die tusschen twee hoogten is nedergestort, gras en aarde, die op een verrotten boomtronk liggen, wat in de

Bila-stroomgebied, Tijdschr. v. h. Ned. Aardr. Gen., 2e serie, dl. III, blz. 507, en Von Rosenberg, Der Malayische Archipel, blz. 33, waaruit blijkt dat het bewaren van de schedels van hen, die men opgegeten had, nog korten tijd geleden bestond. Niet zelden werden deze schedels door de familie van de verslagenen ingelost tegen betaling van eene som gelds.

43 Ibn al-Wardî, gestorven in 1349 n. C., schreef voor den regent van Aleppo

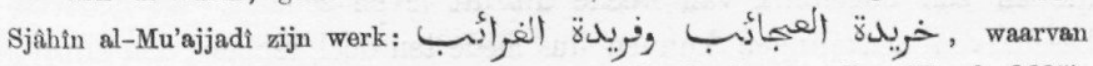
Tornberg een gedeelte heeft uitgegeven met Latijnsche vertaling (Upsala 1835). Het is een cosmographisch werk in den trant van dat van Qazwîn?.

44 Van der Lith, O. c., blz. 246, noot.

4 Behalve eenige aanteekeningen, door mij gemaakt tijdens mijn verblijf in de Bataklanden, heb ik voor het volgende vooral geraadpleegd: Von Rosenberg, Der Malayische Archipel, blz. 59-60; Niemann, Bijdrage tot de kennis van den godsdienst der Bataks, Tijdschr. v. Nederl. Indië, jaarg. 1870, dl. I, blz. 297; Hagen, Beiträge zur Kenntniss der Battareligion, Tijdschr. v. Ind. T. L. en Vk., dl. XXVIII, blz. 512-513; Neumann, Het Pane- en Bila-stroomgebied, Tijdschr. v. h. Nederl. Aardr. Gen., 2e serie, dl. III, blz. 306-307 en 514; Van der Tuuk, Bataksch woordenboek, i. vv. ulubalang en antar; het verhaal "Malim Deman" bij : Van der Tuuk, Bataksche chrestomathie, dl. I, blz. 87 vv., en het overzicht van dit verhaal bij: Niemann, Mededeelingen omtrent de letterkunde der Bataks, Bijdragen tot de T. L. en Vk. v. Nederl. Indië, 3e volgreeks, dl. I, blz. 255 vv., waar (blz. 264-266) eene uitvoerige beschrijving gegeven wordt van de wijze, waarop eene pangulubalang wordt vervaardigd. 
taguk (bamboekoker waarin de palmwijn bij het tappen wordt opgevangen) en wat op den weg omgekomen is, zooals mieren, vlinders en ander gedierte, hout dat door beren vaneen gereten, hout waarin de bliksem geslagen is, en citroenen en welriekende planten. Het voornaamste bestanddeel bij de bereiding van de pangulubalang is echter het hoofd van eenen mensch, die of in den strijd gevallen is, of opzettelijk voor het doel geslacht wordt ${ }^{46}$. In het laatste geval wordt in den regel een ouderlooze knaap genomen van acht tot tien jaren, die tot aan den hals in den grond begraven wordt, terwijl men hem eene brij van gestampte spaansche-peper, gember en zout in den mond stopt. Daar hem daarbij geen enkel druppel water gegeven wordt, geraakt hij in zulk een overprikkelden toestand, dat het niet veel moeite kost, hem te doen beloven, na den dood de dorpsbewoners als schutsgeest te dienen, waarna hij onmiddelijk omgebracht wordt, door hem gesmolten lood in den mond te gieten. Aldus de mededeeling van den Heer Von Rosenberg 17. Niet onwaarschijnlijk is het echter, dat die martelingen nog iets meer zijn dan eenvoudig een middel, om van den knaap de verlangde belofte af te persen. De gemoedsgesteldheid toch, waarin iemand verkeert op het oogenblik van het sterven, bepaalt, volgens de voorstelling van de natuurvolken, rechtstreeks de geaardheid van zijne ziel na den dood. De ziel die vreedzaam het lichaam verlaat, terwijl de betrokken persoon, onbewust van zijn naderend uiteinde, in eene genoegelijke stemming zich bevindt, is een minder gevaarlijke daemon, derhalve ook minder als krijgsgeest geschikt, dan de ziel van hem, die in een oogenblik van woede uit dit leven scheidt. De zooeven beschreven martelingen kunnen dus mede ten doel hebben, den knaap, resp. diens ziel, de vereischte dispositie te verleenen om als schutsgeest op te treden ${ }^{48}$. Is de pangubalang gereed, dan wordt zij

46 Vergelijk ook noot 3la hierboven. In het, in de voorgaande noot genoemde, Bataksche verhaal van "Malim Deman", vinden wij onder anderen een voorbeeld van eene pangulubalang, die gemaakt wortt van den schedel van iemand, die in den oorlog gevallen is.

47 Von Rosenberg, O. c., blz. 59-60. Dr. Hagen (O. c., blz. 513, noot), de mededeeling van Von Rosenberg overnemende, zegt: "Diese ganze Erzählung ist wörtlich wahr, und herrscht dieser Gebrauch auch in den von mir durchforschten Gegenden".

48 Vergelijk ook: Bastian, Die Vorstellungen von der Seele, blz. 40-41, waar het onder anderen heet: "Auch bei den auf Erden in dämonische Dienstlichkeit zu bannenden Seelen mag die so im Todesmomente beherrsohende Stimmung benutzt werden, um sie für ihre weitere Aufgabe geschickt zu machen, Der bei dem 
met vele ceremoniën ingewijd. Dit inwijden heet mangantarhon (van het grondwoord antar) dat is: geleiden, namelijk de ziel in de bereide zelfstandigheid, zooals mij, tijdens mijn verblijf te Sipirok in de Bataklanden, uitdrukkelijk door een datu verzekerd werd. De pangulubalang is dus, door de daarmede vereenzelvigde ziel van den verslagene, een machtige fetis, die van zijnen bezitter allerlei onheilen afweert en diens vijanden als sen voorvechter bestrijdt, zooals de benaming pangulubalang, dat is: die tot ulubalang, voorvechter, dient, vanzelf aanduidt. In tijden van oorlog of van groot gevaar zou zij, wanneer zij goed is, het vermogen hebben om de dorpsbewoners to waarschuwen door een dof trillend geluid te maken, zooals dat van eene groote pauk. Men roept de pangulubalang ook an als eene godheid en brengt haar bij verscheidene gelegenheden, vooral spijzen, als offeranden. Veelal wordt zij bewaard in een beeld, dat ter hoogte van den navel eene opening heeft, en welk beeld aan den ingang van het dorp geplaatst wordt ${ }^{49}$. Soms is het echter een ruwe of een eenvoudig vierkant gehouwen steen, waaronder de pangulubalang geborgen wordt ${ }^{50}$. Moet zij in den krijg dienst doen of bij het bezweren van ziekten, dan wordt zij in den zoogenaamden tungkot-malehat gedaan, een stok of staf met figuren versierd en aan het boveneind waarvan een ruiterbeeld, bij wijze van knop, is angebracht ${ }^{50^{a}}$.

Schedels zijn dus beschermende fetisen. Zoo laat zich ook het feit verklaren, dat men altijd begeerig is om het aantal daarvan te vermeerderen. Immers elke kop, dien men buit maakt, vertegenwoordigt de hulp van een meer of minder machtigen geest. Er zijn echter gevallen, waarin men meer dan anders behoefte heeft, om zich op die wijze in het bezit van eenen fetis te stellen. Zoo bij het oprichten en betrekken van eene nieuwe woning. Het gebruik, om bij derge-

Krönungsfest der Kimbunda geopferte Kriegsgefangene wird in Unkenntniss erhalten über das bevorstehende Geschick und erhält seinen Todesstreich im Taumel fröhlichen Tanzes, wenn sich seine Seele im Lustgefühl bersuscht, damit sie in Fixirung dieser, zu liebevoller Hingabe neigenden, Freudenstimmnng jetzt fortan als anhänglicher Schutzgeist den Fürsten umschweben. Zie ook noot 52 hierbeneden,

40 Dergelijke beelden worden ook aangewend als dragers van andere voorbehoedmiddelen, amuletten, pagar's, en heeten daarom parpagaran (Zie hierover onze verhandeling: Het animisme bij de volken van den Indischen Archipel, blz. 122).

50 Zulk een steen heet batu-tulpak, dat is letterlijk: afweersteen. In het algemeen heet si-patulpak neen afweringsmiddel als die men bij den ingang van een dorp vindt, om een geest of wel een vijand er buiten te houden" (Van der Tuuk, Bataksch woordenboek, i. v. tulpak).

50a Zie Aanteekening II aan het slot van dit opstel. 
lijke gelegenheden menschenoffers te brengen, komt bij tal van volken voor 51. Buitengewoon kenschetsend hiervoor is het veelmaals geciteerde verhaal van koning Maha Mongkut van Siam, die bij den bouw van cene poort drie mannen grijpen en onthoofden liet, na hun opgedragen te hebben, die poort trouw te bewaken, en, bij de nadering van vijanden of van andere gevaren, te waarschuwen 52 . Het is van genoegzame bekendheid, dat dergelijke praktijken voorheen in Europa evenzeer moeten hebben bestaan. In de sagen en volksverhalen vindt men de bewijzen daarvan, waar herhaaldelijk gesproken wordt van kinderen, die in de fundamenten van huizen en kasteelen, muren, bruggen en dijken ingemetseld werden, om aan deze bouwwerken sterkte en duurzaamheid te verleenen, om ze te beschutten tegen het geweld van den vijand of tegen de krachten der natuur, om ze onneembaar te maken of voor instorting en vernieling te bewaren. Bij de volken van den Indischen Archipel zijn deze bouwoffers niet onbekend. Zoo placht men voorheen bij de Alfoeren van de Minahasa, bij den bouw van een huis, onder den hoofdpaal een kind te begraven of eenen schedel, dien men voor dat doel opzettelijk had laten snellen, opdat er zegen in dat huis zou zijn. Ook wanneer de woning voltooid was, moest er een menschenhoofd zijn, dat onder de nok werd opgehangen ${ }^{53}$. Verder zien wij hoe bij de Alfoeren van Ceram evenzeer het gebruik bestaat, om, onder anderen bij het oprichten van een baileu of gemeentehuis, in het gat bestemd voor den middelsten stijl een pas gesneld hoofd, of, bij

${ }^{51}$ Zie hierover: Liebrecht, Zur Volkskunde, blz. 284-296; Andree, Ethnographisohe Parallelen und Vergleiche, blz. 18-23; Tylor, Primitive culture, dl. I, blz. 104-108; Lippert, Christenthum, Volksglaube und Volksbrauch, blz. 457-461; Grimm, Deutsche Mythologie, blz. 1095-1097; Krauss, Das Bauopfer bei den Südslaven, Mittheilungen der Anthropologischen Gesellschaft in Wien, dl. XVII, blz. 16-24; Winternitz, Einige Bemerkungen über das Bauopfer bei den Indern, en Haberland, Ueber das Bauopfer, Mittheilungen der Anthropologisehen Gesellschaft in Wien, dl. XVII, Sitzungsberichte, blz. 37-40 en 42-44; Gittée en Gaidoz, Les rites de la construction, Mélusine, dl. III, kol. 497-498 en dl. IV, kol. 14-18.

52 "Die Seelen", aldus voegt Lippert, die dit verhaal (O. c., blz. 457) eveneens eiteert, er an toe, "sollen aber nicht mit Unlust und Rachegedanken ihren Dienst antreten, sondern fröhlich und mit ihrem Schicksale versöhnt, - darum wird den Männern ein glänzendes Mahl bereitet und bei diesem giebt ihnen der König jenen Auftrag".

${ }^{53}$ Graafland, De Minahasa, dl. I, blz. 286 ; Statistieke aanteekeningen over de residentie Menado, en Van Spreeuwenberg, Een blik op de Minahassa, Tijdschr. v. Nederl. In lië, jaarg. 1840 , dl. I, blz. 119 , en jaarg. 1845, dl. IV, blz. 318; Riedel, De Minahassa in 1825, Tijdschr, v. Ind. T. L. en Vk., dl, XVIII, blz, 503 en 559 , aanteekening 54 . 
gebreke daarvan, een drogen menschenschedel te werpen ${ }^{54}$, een gebruik dat voorheen ook op Ambon en de Oeliasers voorkwam 55. Zuidelijker, op de Timorlaoet-eilanden, treffen wij iets dergelijks aan. Zijn de voor de palen bestemde kuilen gegraven, dan worden daar niet zelden koppen van krijgsgevangenen en van slaven in gedaan 56. Wenden wij ons naar Borneo, dan zien wij dat het bij de Milanau's, een Dajakschen stam in het Noordwesten van het eiland, vroeger gewoonte was, om, wanneer het althans groote woningen gold, bij het inheien van den eersten paal, een menschenoffer te brengen. Daartoe werd er een diep gat in den grond gegraven, waarin, nadat men op den bodem daarvan eene slavin gelegd had, de paal nedergelaten werd, zoodanig dat het ongelukkige slachtoffer daardoor geheel werd verpletterd $\mathbf{5} \mathbf{7}$. Elders op Borneo, onder anderen in het stroomgebied van de Koetei-rivier of de Mahakam, schijnen de voor het bouwoffer benoodigde schedels hoofdzakelijk door middel van het koppensnellen te worden verkregen. De Heer Tromp vermeldt althans, dat bij deze Dajaks het snellen van een hoofd verplichtend is bij het bouwen van eene nieuwe woning ${ }^{\mathbf{5}}$. Hetzelfde is ook bij de Mentawei-eilanders het geval. Alvorens een nieuw huis te betrekken, moet een hoofd gesneld en tentoongesteld worden. Gebeurt dit niet, dan gelooft men, dat het huis, door den invloed der booze geesten, niets anders dan ongeluk, ziekte en dood zou aanbrengen, zoodat niemand het wagen zou, er binnen te treden of er zich in te vestigen ${ }^{59}$. Ook op Java en Sumatra moet eertijds het bouwoffer bestaan hebben. Nog heden ten dage is het bij de Soendaneezen namelijk gebruikelijk, om onder

54 Riedel, De sluik- en kroesharige rassen tusschen Selebes en Papua, blz. 109 en 118 .

55 Riedel, O. c., blz. 63.

56 Riedel, O. c., blz. 286.

57 Spenser St. John, Life in the forests of the far East, dl. I, blz. 35.

58 Tromp, Uit de salasila van Koetei, Bijdragen tot de T. L. en Vk. v. Nederl. Indië, 5e volgreeks, dl. III, blz. 72, en Eene reis naar de bovenlanden van Koetei, Tijdschr. v. Ind. T. L. en Vk., dl. XXXII, blz. 293.

${ }^{59}$ Hinlopen en Severijn, Verslag van een onderzoek der Poggi-eilanden, Tijdschr. v. Ind. T. L. en Vk., dl. III, blz. 330 (De Poggi-eilanden maken, gelijk bekend is, een deel uit van de Mentawei-groep). Bij Vor Rosenberg, De Mentawei-eilanden, Tijdsohr. v. Ind. T. L. en Vk., dl. I, blz. 426 (= Der Malayische Archipel, blz. 199-200) heet het, dat groote feesten ook gegeven worden bij den bouw van een huis, en dat om zulk een feest te kunnen besluiten, "de dood van een of meer menschen wel niet noodzakelijk vereischt, maar toch als eene voorspoed aanbrengende omstandigheid aangemerkt wordt". Tot dat einde wordt er een sueltocht naar een der naburige eilanden ondernomen. 
de fundamenten van eene in aanbouw zijnde woning den kop van eenen buffel, eene geit of eene kip te begraven. Deze kop is een parepeh, een bezweringsmiddel, eene amulet, waardoor men de woning tegen booze machten en invloeden tracht te beveiligen. Voorheen nu werd voor dat doel een menschenhoofd gebezigd. Volgens het volksgeloof zouden er zelfs nog altijd personen zijn, die moorden, alleen om zich meester te maken van de schedels der verslagenen, ten einde deze, bij den bouw van groote steenen woningen, aanzienlijke bruggen en soortgelijke werken, als parepeh te benuttigen ${ }^{60}$. Wat Sumatra betreft, zijn het de bewoners van de Lampongsche Districten van wie wij dit offer medegedeeld vinden. Bij het oprichten van een huis werden dikwijls een of meer slaven gedood, wier koppen men onder de hoofdstijlen begroef $\mathbf{6 1}$.

Uit het medegedeelde zien wij, dat het bouwoffer bij verschillende stammen van den Indischen Archipel bekend is. Op eenen vorm, waaronder het hier en daar voorkomt, hebben wij echter nog de aandacht te vestigen. "Mildert sich die Sitte", aldus Dr. Andree, "aber bleibt die Anschauung von der Nothwendigkeit des Opfers beim Bau zum Schirm und Schutze des letzteren, dann tritt substituirend für den Menschen das Thier als Schlachtopfer ein" 6 2. Zoo ook bij de Indonesische volken. Een voorbeeld daarvan hebben wij zooeven reeds bij de Soendaneezen leeren kennen. Het is toch niet meer de schedel van eenen mensch, lie bij hen als eene amulet, als parepeh, bij den bouw van eene woning, eene brug, enz., dienst doet, doch de kop van eenen buffel, eene geit of eene kip. Ook bij de Milanau's van Noordwest-Borneo is, op dezelfde wijze, voor het menschenoffer, het dierenoffer in de plaats getreden. Toen - aldus verhaalt Spenser St. John - een Dajaksch hoofd eens eenen vlaggestok voor zijne woning wilde oprichten, werd er op den bodem van den daarvoor gegraven kuil, een hoen gelegd en onder den nedervallenden mast verpletterd ${ }^{63}$. Evenzoo worden bij de Timorlaoeteilanders de menschenschedels, die bij den bouw van een huis onder

60 Oosting, Soendasch-Nederduitsch woordenboek, i. v. ayning en het Supplement hierop, i. จ. $\eta^{n} \eta$ «?. De persoon, die door den bouwheer uitgezonden wordt, om een menschenhoofd te bemachtigen, heet tjulik, welk woord men door "koppensneller" zou kunnen vertalen. Zie ook: Coolsma, Soendaneesch-Hollandsch woordenboek, i. vv. tjulik en parepeh.

61 Cornets de Groot, Nota over de slavernij en het pandelingschap in de residentie Lampongsche Distrioten, Tijdschr. v. Ind. T. L. en Vk., dl. XXVII, blz. 459 ,

${ }^{2}$ Andree, Ethnographische Parallelen und Vergleiche, blz. 22.

6s Spenser St. John, Life in the forests of the far Elast, dl. I, blz. 35 , 
de palen worden begraven, niet zelden door de koppen van wilde karbouwen of buffels vervangen ${ }^{64}$. In al deze gevallen is dus het dierenoffer rechtstreeks een substituut van het menschenoffer. Dit behoeft het echter niet altijd te zijn, en onzes inziens gaan de meeste schrijvers, die over dit onderwerp gehandeld hebben, te ver, door zulks te willen aannemen. Men houde toch in het oog, dat de zielen van dieren, evengoed als die van menschen, beschermgeesten kunnen zijn. Duidelijk zien wij dit bij de Alfoeren van Halmahera. Bij hen spelen namelijk de zoogenaamde penjiguru's of krijgsamuletten eene voorname rol. Veelal bestaan deze uit een met wonderkruiden, olie en wortels gevuld potje, dat aan een met rood katoen overtrokken snoer van stukjes houf hangt. De geest van eenen gier, die in het potje gebannen is, maakt dat de eigenaar minstens onkwetsbaar wordt 65 . Overigens is het van genoegzame bekendheid, dat koppen, beenderen en andere lichamelijke overblijfselen van bepaalde dieren vaak als amuletten gedragen worden, ook hier, gelijk vanzelf spreekt, om de ziel, welke men zich met die deelen vereenzelvigd denkt. Niets natuurlijker dus dan dat men zich ook van de bescherming van dergelijke amuletten tracht te verzekeren bij den bouw van een huis. Op die wijze is onzes inziens dan ook het hondenoffer te verklaren, hetwelk bij de Alfoeren van de Minahasa naast het menschenoffer, doch op geheel andere tijdstippen, plaats had, voor de eerste maal, bij het leggen van de vloerbalken, voor den tweeden keer, bij het oprichten van de stijlen, waarop de dakstoel rust, en voor den derden, bij het dekken. Dat men zich met dit offer ten doel stelde, de nieuwe woning voor ongelukken te bewaren, zich beschermgeesten te verschaffen in de zielen van de gedoode dieren, is niet onwaarschijnlijk. De Alfoer zegt dan ook dat honden gekozen worden, dewijl deze zoo moedig zijn ${ }^{60}$. Ook het gebruik bij de Makassaren en Boegineezen, om, bij het bouwen van een huis, onder den voet van den middelsten paal den kop van eenen jaarvogel, buceros cassidix, en van eene landschildpad te begraven, opdat daardoor de voltooiing van het werk niet belet

64 Riedel, De sluik- en kroesharige rassen tusschen Selebes en Papua, blz. 286.

${ }^{65}$ Campen, De godsdienstbegrippen der Halmaherasche Alfoeren, Tijdschr. v. Ind. T. L. en Vk., dl. XXVII, blz. 451. Tie ook hiervoor onze verhandeling: Het animisme bij de volken van den Indischen Archipel, blz. 129-131.

$66 \mathrm{~N}$. P. Wilken, Bijdragen tot de kennis van de zeden en gewoonten der Alfoeren in de Minahasa, Mededeelingen v. w. h. Nederl. Zendel. Gen., dl. VII, ble. $140-141$. 
worde en verder alle ongelukken van de woning verwijderd blijven ${ }^{67}$, kan geheel onafhankelijk van het menschenoffer, en niet als een substituut hiervan, ontstaan zijn. Wat toch de buceros aangaat, in het godsdienstig leven van vele volken van den Indischen Archipel speelt deze vogel, gelijk door den Heer Pleyte, conservator van het Ethnographisch Museum te Amsterdam, in zijne interessante verhandeling "Pratiques et croyances relatives au bucéros dans l'Archipel Indien", met tal van voorbeelden, is aangetoond, eene belangrijke rol $\mathbf{6 8}$. Bovenal geldt de buceros als een bij uitstek dappere vogel, en zoo zien wij dan ook, hoe bij verschilleude stammen, niet alleen koppen, doch ook af beeldingen van deze dieren als fetisen ter bescherming van personen, bepaaldelijk krijgslieden, of van huizen angewend worden. Salomon Müller deelt onder anderen - om hier slechts een enkel voorbeeld aan te voeren - mede, hoe de Dajaks van het benedenstroomgebied der Barito de nokken hunner woningen met uit hout gesneden figuren van den tingang, buceros rhinoceros, versieren, omdat zij dezen als een invloedrijken geluksvogel beschouwen ${ }^{69}$. Het begraven van eenen buceroskop onder den houfdstijl van eene in aanbouw zijnde woning, bij de Makassaren en Boegineezen, is hiermede zeker volkomen analoog ${ }^{70}$. Eindelijk willen wij

67 Matthes, Over de adá's of gewoonten der Makassaren en Boegineezen, Verslagen en Mededeelingen der Koninklijke Akademie van Wetenschappen, Af leeling Letterkunde, 3e reeks, dl. II, blz. 144, Makassaarsch woordenboek, blz. 683, en Boegineesch woordenboek, blz. 872 , i. v. alo.

68 Revue d'Ethnographie, dl. IV, blz. 311 vv., en dl. V, blz. 464 vv. - Zie ook: Kreemer, De Javaan en zijne vogels, Meledeel. v. w. h. Nederl. Zend. Gen., dl. XXXII, blz. 242 vv.

${ }^{60}$ Temmink, Verhandelingen van de natuurlijke geschiedenis der Nederlandsche Overzeesche Bezittingen, Land- en Volkenkunde, blz. 401, tekst en noot 6.

70 De verklaring, door den Makassaar van het gebruik gegeven, is echter eene andere. Door eenen jarvogel en eene landschilpad onder len hoofdstijl te begraven, wordt, zegt hij, de voltooiing van het bouwwerk niet verhinderd en alle ongeluk van de woning geweerd, omdat de jaarvogel alo, de landsohildpad kura heet, en ta-niyalo-alowi, "niet verhinderd worden", ta-nikura-kuraï, "er zal niets kwaads ondervonden worden", beteekent. Dat deze spitsvoudige, op eene vrij gezochte woordspeling berustende, verklaring eerst later moet zijn uitgedacht, toen de oorspronkelijke beteekenis van het gebruik verloren was gegaan, behoeft geen betoog. Intusschen verdient het opmerking, dat nog van eenige andere voorwerpen het gebruik als amuletten, op dergelijke wijze, uit den klank van den nasm wordt verklaard (Zie: Matthes, Over de bissu's of heidensche priesters en priesteressen der Boegineezen, blz. 9), en dit ook elders in den Archipel gebeurt. Zoo vermeldt de Heer Kreemer van de Javanen, dat houders van warong's of garkeukens een takje of stukje hout van den tjamôrô-boom (casuarina) plegen te bewaren, als een sarat-penglarisan, ecn middel om veel to verkonpen. "Immers", zoo heet het, 
nog de aandacht vestigen op de gewoonte bij de Javanen, om onder stuwdammen, ten einde het bezwijken daarvan te voorkomen, een botje van eenen aap te steken ${ }^{71}$. Ook dit is zeker, geheel onafhankelijk van het menschenoffer ontstaan. Botjes van apen worden toch dikwijls als djimat's, als amuletten, aangewend 72 , zoodat het gebruik daarvan ter bescherming van bouwwerken geheel voor de hand ligt72a.

In het voorgaande hebben wij trachten aan te toonen, dat het menschenoffer, resp. het koppensnellen, slechts eene uiting is van de schedelvereering. Natuurlijk kan het echter ook eene offerhandeling in den strikten zin des woords zijn. Zoo bij voorbeeld bij begrafenissen. Het leven hiernamaals is, naar de voorstelling van de natuurvolken, eene voortzetting van dat op aarde. De afgestorvenen hebben dezelfde behoeften als de levenden, en in die behoeften moeten de nagelaten betrekkingen voorzien, willen zij geen gevaar loopen van door de geesten verontrust en gekweld te worden. Uit deze beschouwing zijn de doodenoffers voortgekomen, in de eerste plaats de menschenoffers. Bij de begrafenis, vooral van hoofden en aanzienlijken, is het dan ook regel, dat eenige slaven geslacht worden, opdat zij den overledene naar het schimmenrijk volgen en hem daar dienen zullen. Ook het koppensnellen kan dikwijls op die wijze een doodenoffer zijn. De bezitter van den schedel heeft toch de ziel van hem, aan wien die schedel heeft toebehoord, in zijne macht. Evengoed nu als hij die ziel reeds in dit leven aan zich dienstbaar maken kan, door haar als schutsgeest te bezigen, kan hij haar ook na den dood als slaaf gebruiken. Werkelijk bestaat bij eenige volken de voorstelling, dat men de zielen van hen, die men tijdens het leven gedood en wier schedels men buitgemaakt heeft, in de andere wereld als slaven bezitten zal ${ }^{73}$. Vandaar dan ook het streven, om zooveel mogelijk koppen

"van tjamôro maakt men de verkorting môro, naderen, en zoo moeten de menschen dan wel, omdat men er deze djimat, amulet, op na houdt, naderen, aankomen. Tegen de aantrekkingskracht van zoo'n ding kunnen zij niets doen" (Kreemer, Iets over djimat's, Mededeel. v. w. h. Ned. Zend. Gen., dl. XXXII, blz. 349).

71 Zie de, in het slot van de voorgaande noot, geciteerde verhandeling van den Heer Kreemer, blz. 353.

72 Kreemer, O. c., blz. 352.

72 a Zie Aanteekening III aan het slot van dit opstel.

73 "The opinion of the Idaan", lezen wij onder anderen, "is that all whom they kill, in this world, shall attend them as slaves after death" (Journal of the Indian Archipelagi, dl. III, blz. 556). Somtijds is het buitmaken van den schedel niet 
te bemachtigen. Hoe meer koppen men heeft, hoe rijker men zal zijn in het hiernamaals, hoe meer bediening men daar hebben zal. Het koppensnellen is dus in sommige gevallen een doodenoffer, dat men als het ware bij voorbaat zichzelven brengt. Doch het spreekt vanzelf, dat men van de zielen, die men dus in zijne macht heeft, aan vrienden of bloedverwanten, bij hun vertrek naar het schimmenrijk, er eenige schenken kan. Zoo heeft er dan ook bij de Olo-Ngadju, bij het tiwah- of doodenfeest, eene plechtigheid plaats, waarbij ieder van het gezelschap achtereenvolgens opsomt, hoeveel menschen hij in den strijd gedood of bij het koppensnellen vermoord heeft. De helft dier verslagenen nu wordt in het zielenland slaven van den overledene ${ }^{74}$. Meer echter pleegt men, bij dezen stam, zoowel als bij de overige Dajaks van Borneo en andere volken van den Indischen Archipel, zielen aan de overledenen te geven, door bij de begrafenis opzettelijke sneltochten te ondernemen $\mathbf{7 5}$.

Niet alleen om overledenen bij hun vertrek naar het hiernamaals in het bezit van dienende zielen te stellen, doch ook ten behoeve van andere geesten of goden kan het menschenoffer, resp. het koppensnellen, plaats hebben en dus in den strikten zin des woords eene offerhandeling zijn. Bekend is de geschiedenis van Admetos, koning van Pherai in Thessalië, die, door tusschenkomst van Apollo, van de Moirai de toezegging kreeg, dat hij zou blijven leven, mits op zijn doodsuur een ander het op zich nam, voor hem te sterven, waartoe, nadat allen voor dit offer waren teruggedeinsd, zijne gemalin Alkestis zich bereid verklaarde. Hetgeen aan dit verhaal ten grondslag ligt, vindt men ook bij andere volken, de voorstelling namelijk dat men het door den doodsgod of de booze geesten begeerde

eens een vereischte. Zoo deelt Von de Wall mede, dat, toen hij naar de bovenlanden van Koesan (Zuidoost-Borneo) op reis zou gaan, hij gewaarschuwd werd om voorzichtig te zijn met het eten, "daar de bergbewoners de gewoonte hebben, vreemdelingen te vergeven. Zij gelooven dat de op die wijze vermoorde personen in het andere leven hunne slaven worden" (Overzicht van het rijk van Koetei , Indisch Arehief, jaarg. 1850 , dl. III, blz. 465).

74 Perelaer, Ethnographisohe beschrijving der Dajaks, blz. 250, en Hardeland, Dajaksch woordenboek, i. v. harantong.

75 Zie dit uitvoerig met voorbeelden aangetoond in onze verhandeling: Het animisme bij de volken van den Indischen Archipel, blz. 78 vv. Voor zooveel betreft de Dajaks, speciaal van het stroemgebied der Mahakam of Koetei-rivier, kunnen wij hier bovendien verwijzen naar de belangrijke mededeelingen van den Heer Tromp, in zijn opstel: Uit de salasila van Koetei, Bijdragen tot de T. L. en Vk. v. Nederl. Indië, 5e volgreeks, dl. III, blz. $67 \mathrm{vv}$. Zie ook van denzelfden schrijver: Eene reis naar de bovenlanden van Koetei, Tijdschr. v. Ind. T. L. en Vk. , dl XXXII, blz. 293. 
leven kan behouden, door er een ander leven voor in de plaats te stellen. "When in Peru", aldus lezen wij, "the Inca or some great lord fell sick, he would offer to the deity one of his sons, imploring him to take this victim in his stead" 76 . Van de Galliërs bericht Caesar, dat degenen, welke door eene zware ziekte waren aangetast of in den krijg trokken dan wel andere gevaren te gemoet gingen, ò menschenoffers brachten, ò de gelofte aflegden dat te zullen doen ${ }^{\mathbf{7 7}}$, terwijl de Noorsche sagen van een zekeren koning Oen spreken, die voor een lang leven aan Odin achtereenvolgens negen zijner zonen offerde ${ }^{\mathbf{7 8}}$. Ook van den Indischen Archipel bezitten wij voorbeelden van dit gebruik. Zoo werden voorheen op de Philippijnen "wenn der Fürst im Sterben lag oder sehr schwer krank war, Sklaven geschlachtet, da nach dem dort herrschenden Glauben alle Krankheiten von den Seelen der Vorfahren kamen und also die böse Seele, welche die Krankheit gebracht hätte, sich jetzt der Seele des Getödteten bemächtige und sich mit dieser begnüge," 79. Bij de Javanen waren eertijds menschenoffers, wanneer men zich in gevaren bevond, bij voorbeeld in den oorlog, eveneens bekend. Een voorbeeld daarvan vinden wij in het bekende, aan het Indische Mahâbhârata ontleende Kawi-dichtwerk Bhâratayuddha, waar, bij het verhaal van den strijd tusschen de Pândawa's en de Kaurawa's, medegedeeld wordt, hoe door ieder der partijen, vóór den aanvang van den slag, een menschenoffer gebracht werd ${ }^{\mathbf{8} 0}$. Daar nu deze episode

76 Tylor, Primitive culture, dl. II, blz. 403.

77 De bello gallico VI, 16.

${ }^{78}$ Grimm, Deutsche Mythologie, blz. 40. - Daar men, gelijk wij zooeven gezien hebben, ook de beschikking heeft over de zielen van hen, die men in den strijd gedood heeft, kan men ook deze in ruil geven voor het eigen leven. "Es ist", zegt Lippert, Kulturgeschichte der Menschheit in ihrem organischen Aufbau, dl. II, blr. 303, "ein recht kannibalistischer Zug, irgend einem Geiste für seine Hilfeleistung die Seelen der zu erlegenden Feinde im voraus zu versprechea, ein Zug, der in den dänischen Sagen öfter wiederkehrt. Als König Syward auf dem Krankenlager liegt, da erscheint ihm Einer, der ihm Genesung verheisst, wenn er ihm die Seelen aller derer weihen wolle, die er mit den Waffen erlegen werde".

79 Blumentritt, Ueber die Staaten der philippinischen Eingebornen in den Zeiten der Conquista, blz. 11-12.

${ }^{80}$ De strophe luidt, naar de vertaling van Dr. Van der Tuuk (Bijdragen tot de T. L. en Vk. v. Nederl. Indië, 3e volreeks, dl. I, blz. 413): "Daarop verrichtten zij allen eene offerande op het slagveld; Rawan was de nasm van het slachtoffer van den koning der Pândawa's beginnende; het slachtoffer van den Kuruvorst was een brahman..... Daarom werd hij vervloekt door den tweemaal geborene om met zijn gansehe gezin in het gevecht te sterven". De verklaring van deze strophe stuit intusschen, zooals onder anderen door Prof. Kern (Eene Indische 5e Volgr. IV. 
in het Sanskritsche origineel, in het Mahâbhârata, teneenenmale ontbreekt, mogen wij wel aannemen, dat wij hier met de beschrijving van een Javaansch gebruik te doen hebben ${ }^{\mathbf{8 1}}$. Ten slotte willen wij op de menschenoffers wijzen, die, bij de bewoners van de Soloreilanden en de Balineezen, bij epidemieën voorheen plaats vonden. Bij de eerstgenoemden werd in dergelijke gevallen door den radja eene strook gronds, op een naast het zijne gelegen gebied, aangewezen, waar dan tien tot twaalf personen moesten worden opgevangen en gedood, wier hoofden van den romp gescheiden en binnen de grenzen van het eigen gebied gebracht werden ${ }^{\mathbf{8} 2}$. Nog heden ten dage ge-

sage in Javaansch gewaad, blz. $26 \mathrm{vv}$.) is aangetoond, grootendeels ten gevolge van onze nog gebrekkige kennis der oude taal, op moeielijkheden, die het eenigszins twijfelachtig maken, of hier werkelijk een menschenoffer bedoeld is. De Javanenzelve hebben dit er echter in gezien, zooals uit de moderne omwerkingen van het gedicht blijken kan. "Een menschenoffer", aldus heet het in eene daarvan (BrôtôJudô, uitgave met vertaling van Dr. Cohen Stuart, XII, 5), "wordt door den vorst der Pandôwô's geslacht: Rawan verstrekt hem daartoe. De vorst van Astinô neemt ten offor een priester: met geheel zijn geslacht, zijne kinderen en kindskinderen strekt hij ten offer voor Astinô". Ook in de Maleische redacties van het verhaal wordt uitdrukkelijk van een menschenoffer gesproken. Zie hierover voot 87 en 88 beneden.

81 De beschrijving moet echter eerst later in het dichtstuk zijn ingelascht. Dat zij toch niet van den oorspronkelijken bewerker van het Bhâratayuddha, Mpu Sědah, af komstig is, blijkt reeds daaruit, dat op hetgeen daar verhaald wordt, in den loop van het gedicht verder niet de minste toespeling voorkomt (Zie: Kern, Eene Indische sage in Javaansch gewaad, blz. 27). Overigens ziet men (Dr. Brandes makte er ons indertijd opmerkzaam op), bij eene vergelijking van de geincrimineerde strophe (116) met de daaraan voorafgaande (115) en de daarop volgende (117), hoezeer de eerstgenoemde geinterpoleerd is. Het offer wordt in strophe 116 beschreven: beide partijen worden daarbij voorgesteld als op het slagveld aanwerig te zijn. Intusschen wordt in strophe 115 alleen de aankomst van de Kaurawa's daar ter plaatse vermeld, terwijl eerst in strophe 117 van het verschijnen der Pândawa's gesproken wordt. Eerstgenoemden, de Kaurawa's, hadden Hastinapura in hun bezit. Zij trokken de stad uit en rukten Westwaarts op, onder het schallen van de krijgsklaroenen, hetgeen den strijdlust bijzonder aanwakkerde. "Toen zij dus gedaan hadden", aldus luidt de aanhef van strophe 117, "welaan er worde dan verhaald van de Pândawa's". Ook deze verlieten hunne kuts en trokken in Oostelijke richting, zoodat zij de slagorde der Kaurawa's vóor zich hadden. Niet minder strijdvaardig stelden zij zich op. Dat beidestrophen een doorloopend en aaneensluitend geheel vormen, is duidelijk. Strophe 116, waardoor de geregelde gang van het verhaal zoo zichtbaar afgebroken wordt, moet dus eerst later zijn ingelascht. Misschien dat dit door deu eenen of anderen kenner van de oud-Javaansche gebruiken geschied is, die, wetende dat voorheen bij elken strijd een menschenoffer noodig was, gemeend heeft, van deze handeling ook hier gewag te moeten maken. Inlasschingen komen trouwens in het Bhâratayuddha meer voor (Zie: Kern, Zang XV van het Bhâratajuddha, Bijdragen tot de T. L. en Vk. van Nederl. Indië, 3e volgreeks, dl. VIII, blz. 158 vv.).

82 Kluppel, De Solor-eilanden, Tijdsehr. v. Ind. T. L. en Vk., dl. XX, blz. 394 
schieden dergelijke menschenoffers in schijn bij de Balineézen. In den avond van den 7 Maart 1875, aldus beschrijft de Heer Van Eck zulk een offer, was de bevolking van zekere desa, buiten de kom der gemeente, rondom eene hoog opgerichte stellage verzameld, waarop, tusschen allerlei geslachte kippen, eenden, varkens, enz., benevens de noodige vruchten en bloemen in, een man was nedergelegd. Eerst was het den Heer Van Eck niet recht duidelijk, wat dat lange witte kleed verborgen hield, doch na herhaald vragen werd hem eindelijk, zij het ook nog schoorvoetend, de waarheid verteld. Reeds sedert weken werd de desa door eene epidemie geteisterd. In hare radeloosheid had de bevolking zich tot den priester gewend, die haar, na het daarbij gebruikelijke gebed, bekend maakte, hoe de ziekte niet zou wijken, alvorens de gemeente een harer leden den goden ten zoenoffer had aangeboden. "En ziet u, mijnheer!" aldus werd den Heer Van Eck verder medegedeeld, "dat geschiedt nu. Aan N.N., die daar ligt, is de hooge eer te beurt gevallen van voor zijne medeburgers te mogen sterven. De goden zullen het echter alleen met onzen goeden wil vcorlief nemen en hem ons straks levend teruggeven. Dan wordt N.N. naar de rivier gebracht, om zich te wijden, en keert hij naar den dorpstempel terug, waar hij gedurende drie dagen zich in gebed en boetedoening moet afzonderen". Later vernam de Heer Van Eck, hoe alleen ontzag voor de Hollanders het volk weerhield, om hunnen medeburger werkelijk ter dood te brengen, terwijl het bleek, dat op sommige afgelegen plaatsen in zulke gevallen ook feitelijk een mensch, al behoort deze niet altijd tot de gemeente, wordt ten offer gebracht $\mathbf{8 3}^{3}$.

Het beginsel, om een leven te geven ten einde eens anders, resp. het eigen, leven te behouden, vindt, het is noodig hierop nog de aandacht te vestigể, zijne uiting ook in het koppensnellen. Zoo heeft dit koppensnellen, bij de Dajaks van het stroomgebied der Koetei-rivier of Makaham, onder anderen ook plaats bij de geboorte van eenen zoon en bij het plechtig baden van een kind in de rivier,

85 Van Eck, Schetsen van het eiland Bali, blz. 160-161. Over het voorkomen van menschenoffers op Bali, in tijden van rampen, spreekt ook Dr. Friederich. Zoo moet vroeger een vorst van Karang-Asem, die in den oorlog overwonnen was, een zijuer slaven gedood, en diens lichaam toen, met kleederen bedekt, onder de talrijke offeranden nedergelegd hebben (Friederich, Voorloopig verslag van het eiland Bali, Verhandelingen v. h. Bat. Gen. v. K. en W., dl. XXII, blz. 57). Ook op het naburige Lombok schijnen dergelijke menschenoffers heden ten dagen nog voor te komen (Van Eck, Schets van het eiland Lombok, Tijdschr. v. Ind. T. L. en Vk., dl. XXII, blz. 351). 
waarbij dit dan tevens voor het eerst een koralen halsketting omgedaan wordt, gewoonlijk op den leeftijd van vier of vijf jaren ${ }^{\mathbf{3 4}}$. De reden hiervan ligt voor de hand. Gedurende de eerste levensjaren is het kind, niet alleen aan tal van werkelijke, doch ook aan verschillende vermeende gevaren blootgesteld. Booze geesten en daemonen belagen het, en niets natuurlijker dus dan dat men, voor het door hen begeerde leven, een ander leven in de plaats geeft, door iemand te dooden. Op dezelfde wijze kan ook het koppensnellen bij het intreden der puberteit en bij het huwelijk verklaard worden. Het ligt toch voor de hand, dat men, na eene gelukkig volbrachte kindsheid en bij het intreden van eene nieuwe levensperiode, zich de gunst en de bescherming der goden zal hebben trachten te verzekeren door een menschenoffer $\mathbf{8 4}_{\mathbf{a}}$. Eenigermate komt dit nog uit

84 Tromp, Uit de salasila van Koetei, Bijdragen tot de T. L. en Vk. v. Nederl. Indië, 5e volgreeks, dl. III, blz. 72, en Eene reis naar de bovenlanden van Koetei, Tijdsohr. v. Ind. T. L. en Vk., dl. XXXII, blz. 293.

${ }_{84}$ a Het dierenoffer, dat men dikwijls bij dergelijke gelegenheden gebracht ziet, is natuurlijk op dezelfde wijze te verklaren. Zoo komt bij de Alfoeren van de Minahasa, onder de benaming irojor si-okki, eene plechtigheid voor, waarbij de jonggeborene naar het water gebracht en daar plechtig gebaad wordt. Fierbij wordt er echter niet als ij de Dajaks van de bovenlanden van Koetei een menschenoffer gebracht, doch een varken geslacht. Alvorens moet het wicht, aldus lezen wij, "met de voetjes dit dier driemaal aanraken, hetgeen de moeder op vele plaatsen ook doet, opdat de goden zouden weten, dat het varken ten behoeve van het kind zal geofferd worden" (Graafland, De Minahasa, dl. I, blz. 303). Overigens willen wij, om een zeer bekend voorbeeld aan te halen, hier nog wijzen op het gebruik bij de oude Arabieren, om, als een kind zeven dagen oud was, een schaap te slachten, welk gebruik in eenigszins gewijzigden vorm in den Islâm is overgegaan. Dnidelijk blijkt de bedoeling van deze handeling uit het formulier, dat, volgens Lane (Arabian society in the Middle Ages, blz. 191), bij het dooden van het offerdier, de 'aqiqa zooals dit heet, wordt uitgesproken, een formulier dat, misschien met uitzondering van de slotwoorden, die eerst later daaraan toegevoegd zijn, uit den heidensehen tijd moeten afstammen. "The person", zoo schrijft Lane, "should say, on slaying the victim: O God, verily this 'aqiqa is a ransom for my son such a one; its blood for his blood, and its flesh for his flesh, and its bone for his bone, and its skin for his skin, and its hair for his hair. O God, make it a ransom for my soin from hell fire" (Zie hierover ook onze verhandeling: Ueber das Haaropfer und einige andere Trauergebräuche bei den Völkern Indonesiens, blz. 92). - Om het bedreigde leven te behouden, wordt dus een ander leven gegeven, hetzij dat van eenen mensch of een dier. Bekend is het echter, ten einde dit hier nog volledigheidshalve op te merken, dat men hetzelfde tracht te bereiken, door, met toepassing van het bij de offers veelvuldig geldende beginsel "pars pro toto", een deel van het eigen lichaam af te staan, waarvan onder meer het haaroffer bij geboorten, het intreden van de puberteit en huwelijken, en evenzoo het uitbreken van een of meer tanden, resp. de meer verzachte vorm daarvan, de tandvijling, bij dergelijke gelegenheden, zoovele 
bij de bewoners van de Mentawei-eilanden. De groote feesten bij huwelijken worden namelijk in den regel met eenen sneltocht besloten, daar zulks "Zwar nicht für unumgänglich nöthig erachtet, aber doch als Glück bringende Zugabe angesehen wird" $\mathbf{8 4}$. Bij de meeste volken is echter deze beteekenis geheel verloren gegaan, geldt het koppensnellen in dergelijke gevallen nog alleen om een bewijs van moed te geven, vooral om op die wijze bij de vrouwen in aanzien te komen. Bij sommige volken van den Archipel is dan ook het buitmaken van eenige schedels in zooverre noodzakelijk om te kunnen trouwen, dat geen meisje hare hand zal geven aan iemand, die niet ten minste een afgesneden hoofd als teeken van zijne dapperheid kan vertoonen ${ }^{\mathbf{8 5}}$.

Het is duidelijk dat het menschenoffer, resp. het koppensnellen, ook waar het, gelijk in de laatstbedoelde gevallen, eene offerhandeling in den strikten zin des woords is, een middel kan zijn, om bescherming te erlangen, rampen te keeren. De voorstelling is dan echter, niet dat de ziel van hem, die gedood wordt, zelve als

vitingen zijn (Zie onze zoveven geeiteerde verhandoling: Uebor das Haarspfer und einige andere Tranergebrãuche bei den Valkern lndonesiens, bix. $00 \mathrm{v*}$, verder: Iete wer de mutilatie der tanden bil de wolken wan den Indiselven Arelípel,

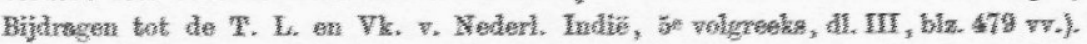
su Von Rusenberg, Der Malayizehe Archipel, bz. 199-200. - Het lan sehter

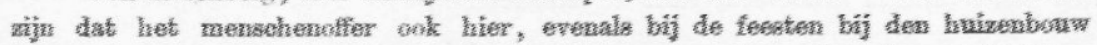
(wie noot 59), eene witing is ₹an de gehedelverecring. Vergelijk sol wow s6 bierbeneden.

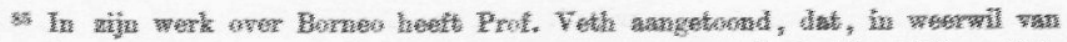
den door sommigen, wnder anderen Sohwaner (Eorneo, dl. I, bliz. 191) en Sal.

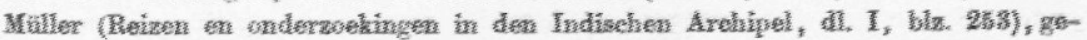

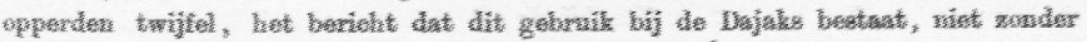

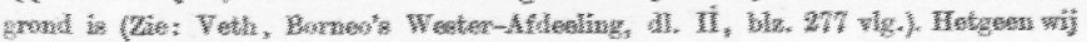

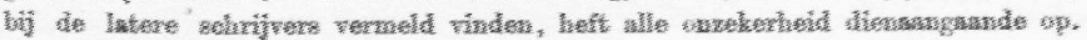

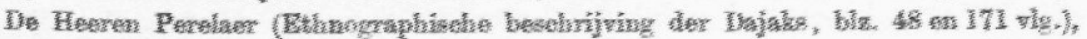

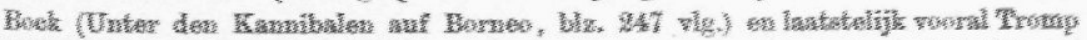

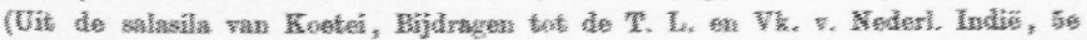

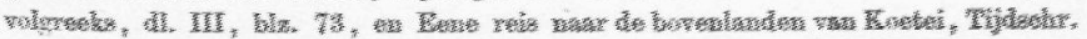

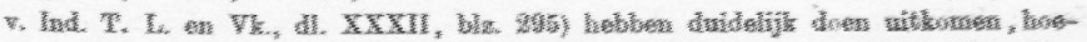

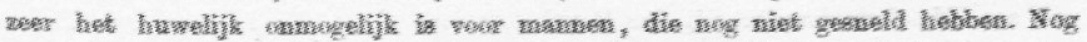

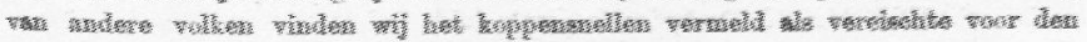

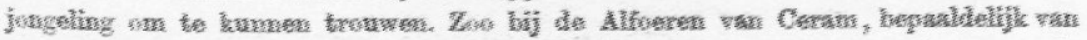

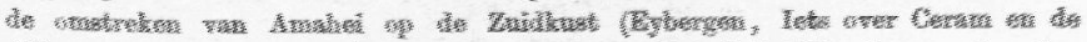

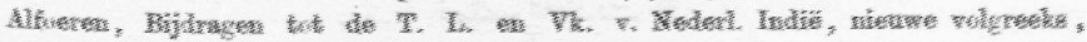

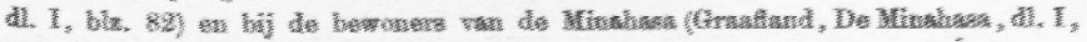

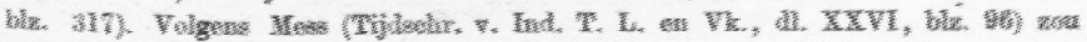

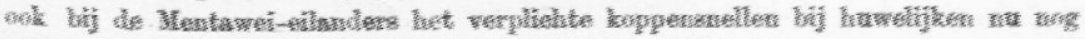

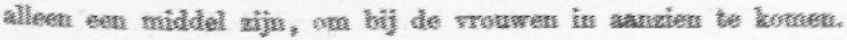


schutsgeest optreedt, doch dat men, door die ziel te schenken aan de godheid, van wie men eenig gevaar te duchten heeft, deze tot toegevendheid stemt en zich van hare hulp en van haren bijstand verzekert. Niet altijd echter is het even duidelijk, met welke van beide voorstellingen men te doen heeft. Zoo bij voorbeeld bij het hiervoren besproken menschenoffer bij de Javanen 86. Naar de bewoordingen van eene der Maleische bewerkingen van het Bhâratayuddha, zou dit offer door de Pânḍawa's en de Kaurawa's voor het begin van deu slag gebracht zijn als een pěmalis, als een middel ter afwending van rampen en ongelukken en van den kwaden invloed van daemonen ${ }^{\mathbf{8 7}}$. Dat men daarbij zich de ziel van het slachtoffer rechtstreeks als een schutsgeest heeft voorgesteld, op de wijze van de pangulubalang bij de Bataks, is zeer wel mogelijk. Toch kan het ook zijn, dat het hier eene offerhandeling in den gewonen zin des woords is geweest, waarbij de verlangde bescherming krachtens het "do ut des" werd verkregen, het bedreigde leven behouden werd door het leven, dat men er vrijwillig voor in de plaats gaf $\mathbf{8}^{\mathbf{8}}$. Ook van het bouwoffer kan het niet altijd met evenveel zekerheid gezegd worden, of het eene uiting der schedelvereering is, dan wel als eene eenvoudige offerhandeling moet worden beschouwd. Dat het toch dit laatste ook kan zijn, wenschen wij nu nog met enkele woorden aan te toonen.

86 Ook, om dit hier op te merken, bij het koppensnellen bij geboorten, huwelijken, enz. Zooeven verklaarden wij dit als eene offerhandeling, krachtens het beginsel, een leven te geven ten einde eens anders, resp. het eigen, leven te behouden. Echter kan het evengoed in sommige gevallen eene uiting zijn van de schedelvereering. Zoo kan het snellen bij de geboorte van een kind ten doel hebben, dit in de ziel van het slachtoffer een schutsgeest te bezorgen. Ook hij die trouwen, een eigen gezin dus vestigen wil, zal vanzelf er op bedacht wezen, zich eenige huisfetisen, eenige penaten, te verschaffen onder den vorm van schedels. Vergelijk ook noot 84b hierboven.

87 Zie: Van der Tuuk, Kort verslag van de Maleische handschriften, toebehoorende aan de Royal Asiatic Society te Londen, Bijdragen tot de T. L. en Vk. van Nederl. Indië, 3e volgreeks, dl. I, blz. 412-413, en Geschiedenis der Pandawa's, naar een Maleisch handschrift der Royal Asiatic Society, Tijdschr. v. Ind. T. L. en Vk., dl. XXI, blz. 27. De bedoelde plaats luidt in laatstgenoemd handschrift:

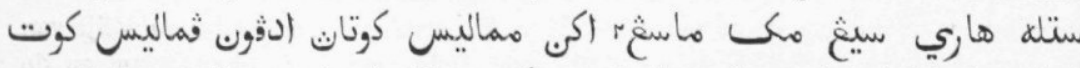

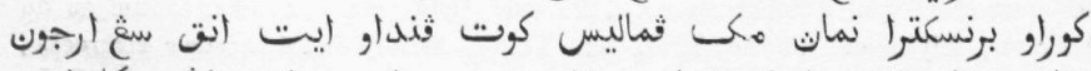

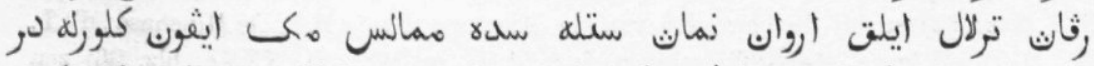

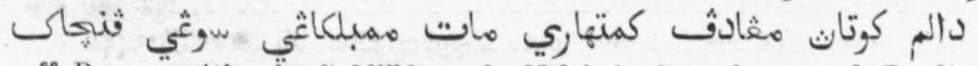

88 Deze opvatting h̆eeft blijkbaar de Maleische bewerker van de Pandjatandaran, 
De godheid, aan wie bij het oprichten van eene nieuwe woning geofferd wordt, om bescherming en afwending van rampen te erlangen, is of de aarde-zelve, natuurlijk anthropopathisch opgevat, als denkend, gevoelend en willend, òf de eene of andere locale geest. Zoo worden bij de bewoners van de Watoebela-eilanden, bij deu huizenbouw, als de gaten in den grond gegraven zijn, vier pakjes met stofgoud of goudvijlsel gereed gemaakt, die men met eenig sirihpinang en tabak op eene zeef doet, en aan de aarde aanbiedt, onder het uitspreken van de woorden: "Vorstin Aarde! maak gebruik van uw goud, uwe rijst; mijne woning wordt hier geplaatst, bewaak mij, dat ik niet ziek worde; laat mij, handel drijvende, veel winnen; laat geene rampen in het huis komen". In elk gat wordt nu een pakje van het klaargemaakte offer gelegd, en de opening goed dichtgemaakt ${ }^{8 \boldsymbol{\theta}}$. Ook op Ceramlaoet wordt, wanneer men eene nieuwe woning bouwt, een offer aan de aarde gebracht, of, zooals het heet, het deel aan den grond gegeven ${ }^{90}$. Hetzelfde gebeurt op Leti-Moa-Lakor en op Kisar. Op de eerste eilandengroep worden er, voordat de middenpalen in den grond gelaten worden, in de daarvoor gemaakte gaten, eenig sirih-pinang en een stuk vleesch zoomede het hart en de lever van eene kip gedaan. "O Vrouw Aarde!" zoo luidt het daarbij gebezigde formulier, "neem de hoofdpalen in uwen schoot, zorg dat deze goed blijven en het beheer voeren over de anderen " ${ }^{91}$. Soms is, zooals reeds werd opgemerkt, het offer voor den eenen of anderen plaatselijken geest bestemd. Bekend is het, dat de Javanen tal van dergelijke plaatselijke geesten vereeren onder den naam van danhjang ${ }^{92}$. Aan deze nu wordt, bij het oprichten

die in eene toespeling op deze episode in het Bhâratayuddha met zoovele woorden zegt, dat het offer geene zonde is, dewijl het beter is dat één sterve dan dat velen te gronde gaan. De plaats luidt (Pandjatandaran, ed. Van der Tuuk, blz. 46-47):

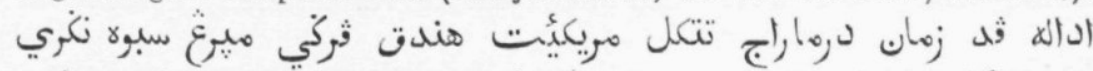

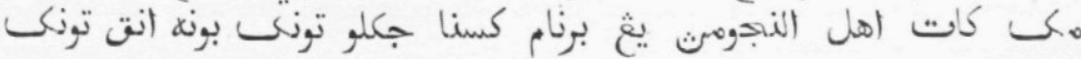

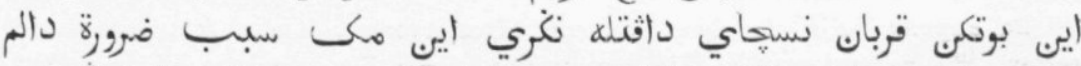

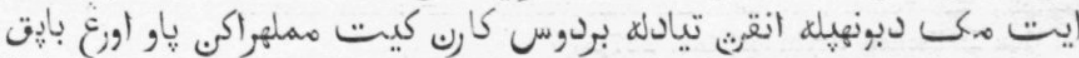
In het Tamilsche origineel ontbreekt deze toespeling (Van der Tuuk, O. c., Aanteekeningen, blz. XXIII), en is deze dus blijkbaar door den Maleischen bewerker. hier ingelasoht.

89 Riedel, De sluik- en kroesharige rassen tussohen Selebes en Papua, blz. 200

90 Riedel, O. c., blz. 161.

21 Riedel, O. c., blz. 380 en 423.

92 Zie onze verhandeling: Het animisme bij de volken van den Indischen Archipel, blz. $243-244$. 
van de stijlen eener nieuwe woning, geofferd, terwijl de pudjonggô, de persoon die als deskundige de werkzaamheden, in de eerste plaats de daarbij in acht te nemen religieuze gebruiken, leidt, de bede uitspreekt: "Danhjang, die deze plaats onder uwe bescherming hebt, ik bied u dit offer aan! Ik verzoek om uwe bewaring! Moge ik toch wèl slagen in het oprichten van dit huis, en dat er geen ongelukken plaats hebben met al hetgeen verder naar de hoogte gaat!" 93 Eene enkele maal is het de voorstelling, dat het offer dienen moet, om den plaatselijken geest, den eigenaar der plek, schadeloos te stellen, opdat deze zich niet op hen, die hem in zijn bezit gestoord hebben, wreken zou. Zijn de houtwerken gereed, dan plaatst, onder anderen bij de Alfoeren van de Minahasa, de huisheer eene mand met rijst en een bord op de bouwplaats, onder het uitspreken van de woorden: "Met deze gave wordt door mij gekocht het erf van de ĕmpung's ${ }^{94}$, waarop mijn huis gebouwd wordt, en ofschoon hier allerlei slechte invloeden werkzaam mochten zijn, zullen ons geene ziekten en rampen treffen, omdat de grond door ons gekocht is geworden" 95 .

Het streven, om bij het oprichten van eene woning zich de bescherming van de Godin Aarde of van den eenen of anderen plaatselijken geest te verzekeren, heeft dus vanzelf tot het bouwoffer geleid. Niet altijd behoeft echter dit offer, gelijk in de zooeven geciteerde voorbeelden, uit zaken, spijs, drank en versnapering, goud of zilver, enz., te bestaan. Ook menschen of dieren kunnen daarvoor gebruikt worden. Werkelijk schijnt, bij enkele van de hierboven genoemde volken van den Indischen Archipel, het mesıschenoffer bij den huizenbouw op die wijze een offer aan eene bepaalde godheid, en niet eene uiting van de schedelvereering, te zijn. Bij de Milanau's in het Noordwesten van Borneo bij voorbeeld, wordt het dooden van eene slavin, door haar onder den hoofdpaal te verpletteren, gezegd "a

93 Poensen, Javaansche woningen en erven, Mededeelingen van wege het Nederl. Zendel. Gen., dl. XIX, blz. 130 vv.

94 De empung's zijn de zielen van de afgestorvenen, doch ook andere goede geesten, die vereerd worden (Zie onze verhandeling: Het animisme bij de volken van den Indischen Archipel, blz. 227).

95 Letterlijk: "En ofschoon hier aanwezig mochten zijn slecht gras, slecht hout en slechte wortels, zullen door het uitdampen daarvan ons geene ziekten en rampen treffen, omdat de grond door ons gekocht is geworden" (Zie: N. P. Wilken, Bijdragen tot de kennis van de zeden en gewoonten der Alfoeren in de Minahasa, Mededeelingen v. w. h. Ned. Zend. Gen., dl. VII, blz. 139-140. Vergelijk ook de verhandeling: Statistieke aanteekeningen over de residentie Menado, Tijdschr. v. Nederl. Indië, jaarg. 1840, dl. I, blz. 119, en Riedel, De Minahasa in 1825, Tijdsohr. v. Ind. T. L. en Vk., dl. XVIII, blz. 503 en 559 , aarteekening 54). 
sacrifice to the spirits" te zijn ${ }^{\mathbf{9}}$, terwijl wij van de Amboneezen uitdrukkelijk medegedeeld vinden, dat de schedel, die onder den stijl van eene in aanbouw zijnde woning begraven wordt, eene offergave is aan Ina Ume of de Moeder Aarde ${ }^{\mathbf{9}} \mathbf{7}$. Hetzelfde wordt ons van de Timorlaoet-eilanders vermeld. Het menschenoffer bij den huizenbouw dient, zooals het heet, om den grond koel te maken, dat is om de aarde, die ook bij hen als eene godheid vereerd wordt,

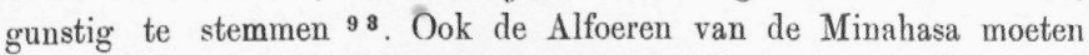
hier genoemd worden. Volgens sommigen toch zouden de zielen van hen, wier 'schedels bij den huizenbouw onder de palen gelegd of die levend daaronder verpletterd worden, bestemd zijn, om de ĕmpung's, de geesten der voorvaderen, in Kasendukan, het godenverblijf, te bedienen en te vergezellen. De plechtigheid zou dan mede ten doel hebben, van die ĕmpung's de beschikking over den te bebouwen grond te verkrijgen ${ }^{\mathbf{9} 9}$. - Het laat zich hooren dat, waar het menschenoffer dit karakter heeft, het ook lichter dan waar het bepaaldelijk eene uiting der schedelvereering is, door het dierenoffer kan worden vervangen. Bij de Amboneezen en de bewoners van de Timorlaoet-eilanden zien wij hoe zelfs, in plaats van dieren, allerlei zaken ten offer gebracht worden, bij de eerstgenoemden een stuk zilver of lood, bij de laatsten een stuk goud en eenige pitten van den kĕmiri (aleurites triloba), soms slechts een weinig water waarin deze voorwerpen een poosje gelegen hebben 100 . Eene dergelijke substitutie is natuurlijk daar, waar het menschen- of dierenoffer gebracht wordt bepaaldelijk om zich in de ziel van het slachtoffer een schutsgeest te verschaffen, niet wel mogelijk.

${ }^{96}$ Spenser St. John, Life in the forests of the far East, dl. I, blz. 35.

${ }^{77}$ Riedel, De sluik- en kroesharige rassen tusschen Selebes en Papua, blz. 63.

${ }^{98}$ Riedel, O. c., blz. 286.

${ }^{90}$ Het offeren van een bord en eene mand met rijst, zooeven bedoeld, zou dan later in de plaats van dit menschenoffer gekomen zijn (Riedel, De Minahasa in 1825 , Tijdschr. v. Ind. T. L. en Vk., dl. XVIII, blz. 503 en 559 , aanteekening 54. Zie ook de verhandeling: Statistieke aanteekeningen over de residentie Menado, Tijdschr. v. Nederl. Indië, jaarg. 1840 , dl. I, blz. 119).

100 Riedel, De sluik- en kroesharige rassen tusschen Selebes en Papua, blz. 63 en 286. 